\title{
DO RECENT AMENDMENTS TO ALBERTA'S MUNICIPAL GOVERNMENT ACT ENABLE MANAGEMENT OF SURFACE WATER RESOURCES AND AIR QUALITY?
}

\author{
JUDY STEWART ${ }^{*}$
}

Since 2015, new provisions have been added to Alberta's Municipal Government Act (MGA) that arguably authorize municipalities to manage components of the environment, such as surface water resources and air quality at the local and regional geopolitical landscape scales. Since 2013, Part 17.1 enabled voluntary formation of "growth management boards" (GMBs) by two or more participating municipalities, and once appointed by the Minister, GMBs are empowered to create "growth plans" to govern growth-related land use decision-making processes within the boundaries of the participating municipalities. Part 17.1 was amended in 2016 and new regulations followed in 2017. City Charter provisions enacted in 2015 give broad governance powers to cities. MGA provisions that create both these new institutional arrangements do not preclude GMBs or cities from developing municipal environmental management objectives. Recent additional MGA amendments enacted as the Modernized Municipal Government Act (MMGA) in December 2016, and further amendments in the spring of 2017 added a preamble, defined "body of water" for the purposes of the MGA, provided for intermunicipal collaborative governance of land use, and amended the environmental reserve provisions and other regulatory aspects of Part 17: Planning and Development. Two new purposes of municipal government were added: "to work collaboratively with neighbouring municipalities to plan, deliver and fund intermunicipal services," and "to foster the well-being of the environment." In this article, amendments to the MGA since 2015 are examined and analyzed in light of Alberta's regional watershed scale land use policy, legislation, and regulations to determine if Alberta municipalities are now authorized to manage the environment, specifically surface water resources and water quality.

\section{TABLE OF CONTENTS}

I. INTRODUCTION . . . . . . . . . . . . . . . . . . . . . . 1010

II. Consistency With Federal And Provincial Enactments . . . . . . 1014

III. THE MGA AND THE ENVIRONMENT, HistoricAlly SPEAKING . . . . . 1018

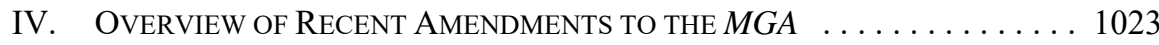

V. GRowth Management BoARds . . . . . . . . . . . . . . . . . . . . 1024

VI. City CHARTERS . . . . . . . . . . . . . . . . . . . . . . . . . . . . . . 1028

VII. THE MMGA AND AN ACT TO

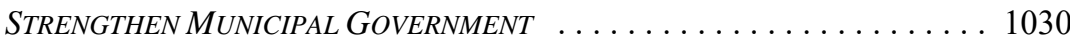

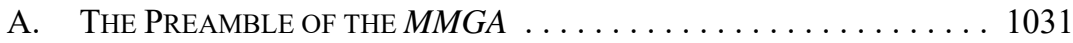

B. NeW Municipal Purposes In THE MMGA AND

An ACt to StRENGTHEN . . . . . . . . . . . . . . . . . 1032

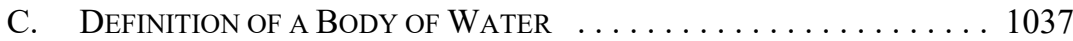

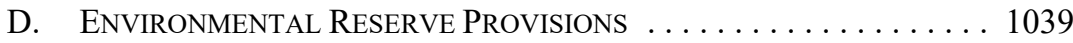

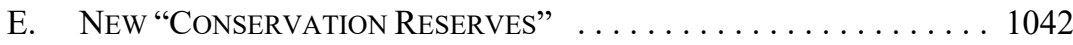

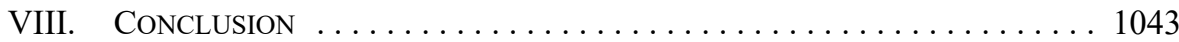

Research Fellow at the Canadian Institute of Resources Law. The author thanks the Canadian Institute of Resources Law for facilitating this project and the Alberta Law Foundation for their generous support. Any errors belong to the author alone. 


\section{INTRODUCTION}

This article explores some of the recent amendments to Alberta's Municipal Government $A c t^{1}$ to determine if municipalities have the authority to manage components of the environment at the local and regional geopolitical landscape scale (hereafter regional scale). The amendments are examined in light of the Alberta Land-use Framework, ${ }^{2}$ the Alberta Land Stewardship Act, ${ }^{3}$ and regional land use regulations. A legislative scheme has emerged whereby the Government of Alberta (GOA) appears to authorize and expect municipalities to manage components of the environment that are owned and managed by the GOA in the public trust. This scheme applies to the environment generally, but also specifically to managing surface water resources and air quality, especially during land use decision-making processes for approving development of private lands. These MGA amendments were enacted between 2015 and 2017, and the associated regulations are still emerging. ${ }^{4}$ There is little academic writing available on this topic, and this article is a significant contribution intended to launch further legal research and opinion, and to help municipalities respond to the new legislation and regulations.

Environmental regulation and environmental management refer to different social-political processes. ${ }^{5}$ Environmental regulation by various levels of government in the British common-law tradition is authority-based. Governments and government institutions use formal and substantive laws (common law, constitutional, and statutory laws and regulations) to regulate human activities related to the use and management of the natural biophysical environment, specific components of the environment, and ecosystem services. For example, in Alberta, the GOA has enacted the Environmental Protection and Enhancement Act, which regulates air emissions that may affect ambient air quality, ${ }^{6}$ and the Water Act, which regulates the diversion and use of all surface and groundwater in the province. ${ }^{7}$ Surface water resources include the environmentally significant features that store or convey water, such

RSA 2000, c M-26 [MGA].

Government of Alberta, Land-use Framework (Edmonton: GOA, December 2008) [LUF].

SA 2009, c A-26.8 [ALSA].

See Bill 8, An Act to Strengthen Municipal Government, 3rd Sess, 29th Leg, Alberta, 2017 [An Act to Strengthen]; Modernized Municipal Government Act, SA 2016, c 24 [MMGA]; Bill 20, Municipal Government Amendment Act, 2015, 3rd Sess, 28th Leg, Alberta, 2015. See also Government of Alberta,

"What's Changing," online: <https://mgareview.alberta.ca/whats-changing/>:

Most of the changes and associated regulations have come into force, with the remaining becoming effective on Jan. 1, 2018 and in April 2018.... A consolidated MGA and the new regulations will be published by the Alberta Queen's Printer and links will be provided once available. All MGA related regulations were reviewed to support a modernized $M G A$ and to ensure alignment with the amendments approved by the legislature in 2015 and 2016. Drafts of the reviewed regulations are being posted for public review and comment in several groupings. A third grouping of MGA Review related draft regulations is expected to be posted on the Regulations Review page for public review and comment in early 2018.

See Judy Mary Mattie Stewart, A Reflexive Legal Framework for Bridging Organizations in Regional Environmental Governance and Management (PhD Thesis, University of Calgary, Faculty of Environmental Design, 2016) [unpublished] [Stewart, Reflexive Legal Framework]. Stewart explains the differences between government regulation of the environment, and environmental governance in the context of multi-stakeholder organizations working in collaboration with provincial and municipal governments. Stewart provides a list of 30 environmental management activities that some municipalities engage in within the Calgary Metropolitan Area of Alberta.

RSA 2000, c E-12 [EPEA].

RSA 2000, c W-3. See section 1(ggg):

"[W]ater body" means any location where water flows or is present, whether or not the flow or the presence of water is continuous, intermittent or occurs only during a flood, and includes but is not limited to wetlands and aquifers but does not include except for clause (nn) and section 99 "water body" that is part of an irrigation works if the irrigation works is subject to a licence and the irrigation works is owned by the licensee, unless the regulations specify that the location is included in the definition of water body. 
as beds and shores of water bodies as defined in the Water Act, natural drainage courses, wetlands, lakes, springs and seeps, flood hazard areas, and riparian lands adjacent to water bodies. "Depending on the mandate and level of authority, environmental regulation accords with government policy and legislation, and involves the use of coercive powers based in executive privilege and substantive laws." ${ }^{\circ}$

Further, environmental regulation and environmental governance are not the same. Claudia Pahl-Wostl explained the differences between these concepts in the context of governance and management of natural resources (for example, surface water resources and air), as follows:

\begin{abstract}
"Resources management" refers to the activities of analysing and monitoring, developing and implementing measures to keep the state of a resource within desirable bounds. The notion of "resource governance" takes into account the different actors and networks that help formulate and implement environmental policy and/or policy instruments. Governance embraces the full complexity of regulatory processes and their interaction. ${ }^{9}$
\end{abstract}

For the purpose of this article, environmental management means the activities of analysing and monitoring, and developing and implementing measures to keep the state of the components of the environment within desirable bounds. It is acknowledged that the GOA and the federal government have retained all responsibility for environmental regulation and enforcement of compliance with substantive environmental laws. Through ALSA regional land use regulations and management frameworks, the GOA has also established the so-called "desirable bounds" within which surface water quality and air quality must be sustained to support both human health and well-being, and the health and well-being of all other living things. It is proposed that, when the legislative scheme for regulating and managing regional land use is combined with recent amendments to the $M G A$, municipalities are not only authorized, but are expected to participate in environmental management activities at both the local and regional scales.

In 1994, the GOA enacted the MGA. Since then, legal opinions regarding whether the MGA granted municipalities authority to manage components of the local environment have varied. The answer usually depended on what a municipal government was trying to achieve

Stewart, Reflexive Legal Framework, supra note 5 at 18.

Claudia Pahl-Wostl, "A Conceptual Framework for Analysing Adaptive Capacity and Multi-Level Learning Processes in Resource Governance Regimes" (2009) 19 Global Environmental Change 354 at 355. See also Jan Kooiman et al, "Interactive Governance and Governability: An Introduction" (2008) 7:1 J Transdisciplinary Environmental Studies 1 at 3, where they provide valuable insights about the differences: "governance considers longer term trends and requirements with regard to natural resources, basing itself on an assessment of institutions and a discussion of the values to be attained. Policy deals with specific subjects in tighter time frames, whereas management grapples with the practical dimensions of its implementation." Similarly, governance and government regulation are not the same: see Gerry Stoker, "Governance as Theory: Five Propositions" (1998) 50:155 Intl Social Science J 17. Stoker best explained the governance model in five governance propositions at 17-18, as follows:

1. Governance refers to a set of institutions and actors that are drawn from but also beyond government.

2. Governance identifies the blurring of boundaries and responsibilities for tackling social and economic issues.

3. Governance identifies the power dependence involved in the relationships between institutions involved in collective action.

4. Governance is about autonomous self-governing networks of actors.

5. Governance recognizes the capacity to get things done which does not rest on the power of government to command or use its authority. It sees government as able to use new tools and techniques to steer and guide. 
through resolution or bylaw, ${ }^{10}$ and what part of the $M G A$ the municipality was relying on to achieve its environmental management objectives. ${ }^{11}$ Fact patterns, the wording and interpretation of specific statutory provisions, and legal precedents arising from Canadian court decisions about municipal jurisdiction to manage components of the environment all affected legal opinions on the question, and still do. While municipalities may have considered environmental matters during statutory land use planning exercises and land use development decision-making processes, generally, they did not manage components of the environment through local bylaws or actively participate in environmental management activities. $^{12}$

"Environment" is not defined in the MGA, although the term is used in both the preamendment and post-amendment contexts. Air, land, and water are the primary components of the environment, as the term is currently defined in the EPEA, as follows:

"[E]nvironment" means the components of the earth and includes

(i) air, land and water,

(ii) all layers of the atmosphere,

(iii) all organic and inorganic matter and living organisms, and

(iv) the interacting natural systems that include components referred to in subclauses (i) to (iii). ${ }^{13}$

The statute's in pari materia rule of statutory construction may be used to import the EPEA definition of environment into the MGA. In Black's Law Dictionary, in pari materia means: "On the same subject; relating to the same matter. It is a canon of construction that statutes that are in pari materia may be construed together, so that inconsistencies in one statute may be resolved by looking at another statute on the same subject."14

Therefore, for the purposes of this article, the EPEA definition of environment is used throughout. The environment includes air, land, and water, the atmosphere, organic and inorganic materials and living organisms, and the interacting natural systems among all these components or, in other words, ecosystems as they exist in place and time. The Dictionary of Canadian Law defines an ecosystem as a "dynamic complex of plant, animal and microorganism communities and their non-living environment interacting as a functional unit." 15 Humans are part of all ecosystems, and have become dominant components affecting all others, ${ }^{16}$ creating complex, dynamic social-ecological systems where society and the ecosystem are inextricably connected..$^{17}$

$10 \quad$ See MGA, supra note 1, s 180: "A council may act only by resolution or bylaw." Section 180 also explains when a council may act by resolution or bylaw.

11 The MGA is divided into 18 parts. While all parts are interrelated and important, this article focuses on Parts 1 through 4, and Part 17, Part 17.1, and the newly added Part 17.2.

See Stewart, Reflexive Legal Framework, supra note 5.

EPEA, supra note 6, s 1(t) [emphasis added].

Black's Law Dictionary, 8th ed, sub verbo "in pari materia."

The Dictionary of Canadian Law, 4th ed, sub verbo "ecosystem."

See ME Tyler \& MS Quinn, "Identifying Social-Ecological Couplings for Regional Sustainability in a Rapidly Urbanizing Water-Limited Area of Western Canada" (2013) 173 WIT Transactions on Ecology \& Environment 175 .

17 Fikret Berkes \& Carl Folke, eds, Linking Social and Ecological Systems: Management Practices and Social Mechanisms for Building Resilience (Cambridge: Cambridge University Press, 1998) at 4. A social-ecological system is defined as "the integrated concept of humans-in-nature." 
Governance and management of ecosystems and components of the environment, such as air, land, and water, are inherently transboundary and transjurisdictional, ${ }^{18}$ because they do not respect human-made political boundaries and regulatory regimes. ${ }^{19}$ Municipal land use decisions about how private landowners develop their lands may impact entire socialecological systems ${ }^{20}$ at a regional scale. ${ }^{21} \mathrm{~A}$ decision made by a municipality in the headwaters of a watershed, or upstream in an airshed that does not require a land developer to manage potential impacts on the environment at a regional scale, may have significant negative consequences on downstream communities. Citizens in the upstream municipality may benefit from such a land use development decision, but citizens downstream may bear the burden of unintended consequences. Therefore, it is important to determine whether municipalities have jurisdiction and are expected to manage components of the environment, such as surface water resources and air quality, in terms of both legislative authority and the corresponding responsibilities to citizens at both the local and regional scales. It is also important to determine if recent amendments to the MGA provide additional powers to the delegated authority municipalities have for regulating and controlling land use on privately owned lands through land use bylaws.

This article is presented in eight parts. Part II provides some background information about why municipal bylaws to manage components of the environment, specifically surface water resources and air quality, must be consistent with federal and provincial laws, and why the GOA might want municipalities to manage these components of the environment at the local and regional scales. Part III presents the pre-amendment history of municipal management of the environment pursuant to the MGA. Part IV provides an overview of recent amendments to the MGA since 2015 considered in this article. Parts V and VI explore two new institutional arrangements whereby municipalities have been granted broad new powers that might include management of the environment: (1) growth management boards $(\mathrm{GMB})^{22}$ and (2) City Charters. ${ }^{23}$ Part VII examines specific amendments provided in the MMGA that arguably bolster municipal authority for environmental management at the local and regional scales. The conclusion follows.

Ibid; see also Tyler \& Quinn, supra note 16.

Örjan Bodin \& Christina Prell, eds, Social Networks and Natural Resource Management: Uncovering the Social Fabric of Environmental Governance (New York: Cambridge University Press, 2011) at 6:

[E]cosystems stretch across human-made jurisdictions and administrative borders such as

municipalities, provinces, and states. As a result of this and other factors, natural resources are often characterized by ineffective institutional arrangements and with multiple actors and stakeholders competing for resource use and extraction often leading to overexploitation and the inability to account for dynamic ecosystem processes.

See Berkes \& Folke, supra note 17.

21 See Lance H Gunderson \& CS Holling, eds, Panarchy: Understanding Transformations in Human and Natural Systems (Washington, DC: Island Press, 2002). The authors describe the importance of the regional scale for the purpose of governance and management of the environment and complex, adaptive systems.

22 MGA, supra note 1 , Part 17.1

23 Ibid, Part 4.1 [city charter legislation]. 


\section{CONSISTENCY WiTh \\ Federal AND Provincial EnaCtMents}

Municipalities are not a level of government, but are creatures of the provincial government, exercising the powers granted to them by legislatures in accordance with the Canadian Constitution Act, $1867 .{ }^{24}$ As such, Alberta municipalities must ensure that there are provisions in the MGA that grant them powers to manage components of the environment, such as surface water resources and air quality, before they pass bylaws to achieve management objectives. Furthermore, municipal bylaws must be enacted for a municipal purpose ${ }^{25}$ and must be consistent with provincial and federal enactments, or they will be deemed to be ultra vires and of no force and effect. ${ }^{26}$

Three municipal purposes were listed in the MGA pre-amendments: "(a) to provide good government, (b) to provide services, facilities or other things that, in the opinion of council, are necessary or desirable for all or a part of the municipality, and (c) to develop and maintain safe and viable communities." 27 Generally, municipal bylaws to regulate or control human activities and interactions in the environment have been enacted under the third municipal purpose, 'to develop and maintain safe and viable communities.' Some councils have determined that protecting the health of the local environment is a matter of public safety, and they consider themselves to be custodians of the environment in the public interest. This ideology was articulated by Justice Lacourcière for the Ontario Court of Appeal in Scarborough (Borough) v. R.E.F. Homes Ltd., where she explained when reviewing a municipal decision about a road allowance, "the municipality is, in a broad general sense,

$24 \quad$ See Constitution Act, 1867 (UK), 30 \& 31 Vict, c 3, s 92(8), reprinted in RSC 1985, Appendix II, No 5: "[i]n each Province the Legislature may exclusively make Laws in relation to Matters coming within the Classes of Subjects next hereinafter enumerated; that is to say ... 8. Municipal Institutions in the Province." See also 114957 Canada Ltée (Spraytech, Société d'arrosage) v Hudson (Town), 2001 SCC 40, [2001] 2 SCR 241 at para 49 [Spraytech]:

A tradition of strong local government has become an important part of the Canadian democratic experience. This level of government usually appears more attuned to the immediate needs and concerns of the citizens. Nevertheless, in the Canadian legal order, as stated on a number of occasions, municipalities remain creatures of provincial legislatures.... Municipalities exercise such powers as are granted to them by legislatures. This principle is illustrated by numerous decisions of our Court (see, for example, Montréal (City of) v. Arcade Amusements Inc., [1985] 1 S.C.R. 368; R. v. Sharma, [1993] 1 S.C.R. 650). They are not endowed with residuary general powers, which would allow them to exercise dormant provincial powers (see I. M. Rogers, The Law of Canadian Municipal Corporations (2nd ed. (loose-leaf)), Cum. Supp. to vol. 1, at pp. 358 and 364; J. Hétu, Y. Duplessis and D. Pakenham, Droit Municipal: Principes généraux et contentieux (1998), at p. 651). If a local government body exercises a power, a grant of authority must be found somewhere in the provincial laws. Although such a grant of power must be construed reasonably and generously (Nanaimo (City) v. Rascal Trucking Ltd., [2000] 1 S.C.R. 342, 2000 SCC 13), it cannot receive such an interpretation unless it already exists. Interpretation may not supplement the absence of power [emphasis added].

See also $R v$ Greenbaum, [1993] 1 SCR 674 at 687: "[m]unicipalities ... can exercise only those powers which are explicitly conferred upon them by a provincial statute."

MGA, supra note 1, s 3 .

Ibid, s 1(j):

"[E]nactment" means

(i) an Act of the Legislature of Alberta and a regulation made under an Act of the Legislature of Alberta, and

(ii) an Act of the Parliament of Canada and a statutory instrument made under an Act of the Parliament of Canada,

but does not include a bylaw made by a council. 
a trustee of the environment for the benefit of the residents in the area of the road allowance and, indeed, for the citizens of the community at large." 28

The general jurisdiction to pass bylaws set out in the MGA Part 2: Bylaws and Part 3: Special Municipal Powers and Limits on Municipal Powers are often relied upon by municipalities to achieve safe and viable communities, including protecting components of the environment in the public interest. Parts 2 and 3 enable municipal regulation through bylaws of specific human activities and behaviours associated with nuisances and pollution of the local landscape, surface water and groundwater resources, and air quality. However, in Alberta, the concept of community development is often interpreted by councils as "land development." Municipalities have certain delegated powers for land use planning and development of privately owned lands through Part 17: Planning and Development of the MGA. Generally, Part 17 provides authority for municipalities to pass a land use bylaw to prohibit, or regulate and control impacts of land use and development on certain components of the local environment, and this delegated authority is discussed further in this article.

The meaning of inconsistency and what constitutes true conflict between a municipal bylaw and a provincial or federal enactment was considered by the Supreme Court of Canada in Spraytech. ${ }^{29}$ There, the Supreme Court referred to the Quebec decision of Huot c. StJérôme (Ville de), ${ }^{30}$ as follows: "[TRANSLATION] A finding that a municipal by-law is inconsistent with a provincial statute (or a provincial statute with a federal statute) requires, first, that they both deal with similar subject matters and, second, that obeying one necessarily means disobeying the other." 31

In Spraytech, the Supreme Court reviewed earlier court decisions from across Canada about municipal jurisdiction to pass bylaws, and clarified that dual compliance is certainly possible: a person or corporation may be required to comply with both a municipal bylaw and a provincial or federal statutory provision, as long as obeying one does not mean violating the other. When a potential conflict exists between a municipal bylaw validly enacted to achieve a municipal purpose and a provincial or federal enactment on similar subject matter, the courts will apply a two-part dual compliance test. First, they will determine whether it is possible to obey both laws at the same time, and if so, then they will determine whether the municipal bylaw frustrates the purpose of the federal or provincial law. ${ }^{32}$ If a person is able to comply with the bylaw and the provincial or federal law at the same time, and the bylaw does not frustrate the purpose of the provincial or federal law, then the bylaw will likely be upheld by the court. ${ }^{33}$ Therefore, it is reasonably foreseeable that municipalities might manage local surface water resources and air quality through local bylaws that are consistent, in compliance, and do not frustrate the purpose of federal or provincial enactments.

28

was referenced by the Supreme Court of Canada.

Spraytech, supra note 24 at para 38, citing British Columbia Lottery Corp v Vancouver (City) (1999), 169 DLR (4th) 141 (BCCA): "[t] he court summarized the applicable standard as follows: "A true and outright conflict can only be said to arise when one enactment compels what the other forbids." (1993), JE 93-1052 (Sup Ct).

Spraytech, supra note 24 at para 38 , citing ibid.

See Canadian Western Bank v Alberta, 2007 SCC 22, [2007] 2 SCR 3 at paras 69-73.

MGA, supra note 1, s 13: "[i]f there is a conflict or inconsistency between a bylaw and this or another enactment, the bylaw is of no effect to the extent of the conflict or inconsistency." 
In Alberta, federal and provincial environmental policies, laws, regulations, guidelines, codes of practice, directives, and so on, create a complex government regulatory system. Since 1992 when the EPEA was enacted, the GOA has worked with the federal government and local governments when implementing the EPEA and the regulations in a complex environmental governance and management system. Recently the GOA referred to this system as Alberta's "Integrated Resource Management System" (IRMS). ${ }^{34}$ The GOA articulated that regional land use plans, enacted as regulations under ALSA, are important components of the IRMS. ${ }^{35}$ Since the enactment of $A L S A$, the Minister or Director acting under any provision of the EPEA "must act in accordance with any applicable [ALSA] regional plan." 36 The Crown is bound by ALSA. All decision-makers approving land use and development on public land that may potentially negatively impact the watershed and airshed must comply with regional land use plans. By the end of June 2018, only two regional land use plans exist: the South Saskatchewan Regional Plan 2014-2024 and Lower Athabasca Regional Plan $2012-2022 .{ }^{37}$ Municipalities acting under Part 17 of the MGA with respect to regulating and controlling land use on private lands are also required to comply with $A L S A$ and regional land use plans. ${ }^{38}$

In the SSRP, the GOA has clarified that municipalities are expected to manage local impacts on the environment during land use decision-making processes when approving land development of private lands in the South Saskatchewan land use region. ${ }^{39}$ Under the previous Alberta Land Use Policies ${ }^{40}$ that were put in place shortly after the MGA was enacted, Alberta municipalities throughout the province were "encouraged" to manage such impacts. Since ALSA was enacted, the LUPS are automatically replaced when regional land

34 See Government of Alberta, 2013-14 Annual Report: Consolidated Financial Statements and Measuring Up (Edmonton: GOA, 2014) at 89: IRMS is based on cumulative effects management of energy, mineral, forest, agriculture, land, air, water and biodiversity resources:

A fully functional integrated resource management system will:

- integrate and align natural resource and environmental policies;

- provide clear environmental, economic, and social outcomes to guide all parties operating on the landscape;

- assure the outcomes, policies, and plans advance the public interest;

- create a robust program to measure, evaluate and report environmental, economic and social conditions and outcomes;

- build strong relationships with partners and stakeholders through meaningful engagement;

- provide open and transparent environmental, economic and social data to assist natural resource management decision-making; and

- use Alberta's experience and innovation, as well as the expertise and experiences of others, to continually improve the system.

See also Tracy Price, "Integrated Resource Management System," Alberta Environment and Parks, online: College of Alberta Professional Forest Technologists < https://www.capft.ca/tiny_uploads/ forms/SS20170225 IRMS PriceTracy.pdf>.

35 See Giorilyn Bruno, “Alberta’s ‘Integrated Resource Management System’: Where Are We Now?” (23 December 2015), ABlawg (blog), online: < https://ablawg.ca/2015/12/23/albertas-integrated-resourcemanagement-system-where-are-we-now/>.

36 EPEA, supra note 6, s 3.1.

37 Government of Alberta, South Saskatchewan Regional Plan 2014-2024 (Edmonton: GOA, 2017) [SSRP]; Government of Alberta, Lower Athabasca Regional Plan 2012-2022 (Edmonton: GOA, 2012) [LARP]. See SSRP, ibid at 8: "[p]ursuant to section 15(1) of the Alberta Land Stewardship Act, Regulatory Details are enforceable as law and bind the Crown, decision-makers, local government bodies and subject to section 15.1 of the Alberta Land Stewardship Act, all other persons."

MGA, supra note 1 , s 630.2 .

SSRP, supra note 37 at $105-13$.

Government of Alberta, Land Use Policies (Edmonton: GOA, 1996) [LUPS]. Alberta Municipal Affairs provided provincial policy on municipal management of provincial resources, such as natural resources and water resources during subdivision and development processes. Water resources include river and stream corridors, ravine systems and wetlands, and beds and shores of provincially owned water bodies. Similar policies now appear in Alberta's regional land use plans in Alberta: see especially the SSRP, ibid. 
use plans are adopted for a watershed planning area. Municipal decision-makers in the SSRP planning area are now required to comply with the SSRP which provides the GOA's expectations that municipalities will participate in management responses set out in the South Saskatchewan Surface Water Quality Management Framework, ${ }^{41}$ and the South Saskatchewan Air Quality Management Framework ${ }^{42}$ through enactment and enforcement of local bylaws. The GOA does not limit these tools to local land use bylaws, but references local bylaws generally. ${ }^{43}$ A problem arises, because very few municipalities have management bylaws in place for surface water resources and air quality, although some communities have been proactive in this regard. For example, some municipalities have bylaws to restrict public access to environmentally significant areas consisting of surface water resources associated with riverine and lakeshore communities that have been transferred to municipalities as environmental reserves during subdivision processes. ${ }^{44} \mathrm{Few}$ municipalities have local air quality management bylaws in place, for example, anti-idling bylaws, ${ }^{45}$ or bylaws that restrict the use of wood-burning stoves. ${ }^{46}$

In the South Saskatchewan planning region, the GOA expects municipalities to participate as decision-making partners in managing the environment at the local and regional scales as part of the regional land use cumulative effects and adaptive management processes. ${ }^{47}$

In this article, two main propositions are discussed, as follows:

(1) In the past, municipalities were encouraged to manage the impact of land development of privately owned lands on components of the environment through Part 17 decision-making processes, and they will now be expected and responsible to do so.

Government of Alberta, South Saskatchewan Region-Surface Water Quality Management Framework (Edmonton: GOA, 2014) [Surface Water Quality Management Framework]. See especially Part 6 of the Surface Water Quality Management Framework, where municipal bylaws are considered an appropriate management response tool for surface water quality management at all three levels where management responses are required by land use decision-makers (ibid at 45). See also SSRP, supra note 37 at 32:

The development and implementation of environmental management frameworks is a new approach being used by the Government of Alberta to accomplish cumulative effects management. Management frameworks establish outcomes and objectives along with the strategies and actions to achieve them. The frameworks are intended to provide context within which decisions about future activities and management of existing activities should occur. They confirm regional objectives and establish thresholds. They are intended to add to and complement, not replace or duplicate, existing policies, legislation, regulation and management tools.

Government of Alberta, South Saskatchewan Region-Air Quality Management Framework (Edmonton: GOA, 2014) [Air Quality Management Framework].

$43 \quad$ See Surface Water Quality Management Framework, supra note 41 at 45; Air Quality Management Framework, ibid at 35 .

$44 \quad$ See Judy Stewart, Model Land Use Bylaw: Lakeshore Development Provisions for Conservation and Management of Riparian Lands and Uplands to Minimize Nutrient Loading and Pollution of Pigeon Lake (Edmonton: Pigeon Lake Watershed Management Plan Steering Committee, 2013).

45 But see Town of Okotoks, by-law 18-15, A Bylaw of the Town of Okotoks in the Province of Alberta to Regulate Vehicle Idling (28 September 2015). The bylaw was passed in 2015 under the authority granted through the Traffic Safety Act, RSA 2000, c T-6, s 13, whereby a municipality may, by bylaw, regulate, control, and prohibit the stopping, standing, or parking of vehicles in the municipality, and through the MGA, supra note $1, \mathrm{~s} 7$.

46 Rocky View County requires a building permit for wood burning stoves: see "Wood Stoves \& Fireplaces," online: < https://www.rockyview.ca/Portals/0/Files/BuildingPlanning/Building/brochures/ Wood-Stoves-and-Fireplaces_Information-Brochure.pdf $>$.

47 See SSRP, supra note 37 at $3 \overline{2}$. 
(2) A statutory or legislative scheme has emerged that authorizes municipal environmental management consistent with, and in compliance with, federal and provincial enactments. Through ALSA and recent amendments to the MGA, the GOA has provided municipalities with the authority and responsibility for managing human impacts on components of the environment, such as surface water quality and air quality, not only through Part 17, but through enactment and enforcement of other municipal bylaws as well.

Before discussing the legislative scheme and the recent amendments to the MGA that provide this authority, it is important to determine if any provisions of the pre-amendment MGA authorized municipal management of any components of the environment, and if so, how.

\section{THE MGA AND THE ENVIRONMENT, HISTORICALLY SPEAKING}

In 1994, the GOA granted broad bylaw-passing powers to municipal councils to address emerging issues of a local nature within their boundaries, ${ }^{48}$ or that could take effect in another municipality by agreement. ${ }^{49}$ Although "the environment," is referenced here and there in the MGA, the issue of whether the MGA empowers municipalities to manage the environment was never clearly resolved, although some municipalities did pass bylaws under different parts of the MGA to manage some components of the local environment. It might be that many municipal councils were reluctant to pass bylaws to manage components of the local environment without clear and overt delegation from the GOA, which a court might determine to be ultra vires. Additionally, with limited finances to address all three of the municipal purposes set out in the MGA, municipalities might not have been able to justify allocating budget or personnel to managing components of the environment. Many municipal councils and administrators considered environmental management to be the sole responsibility of the GOA pursuant to EPEA and other provincial legislation, and the federal government. This ideology was addressed in British Columbia v. Canadian Forest Products Ltd., ${ }^{50}$ where the Supreme Court of Canada explained that government protection and stewardship of the environment is a major Canadian value and challenge of our time, and that generally, the Crown is responsible for protecting the environment in the public interest:

As the Court observed in R. v. Hydro-Québec, [1997] 3 S.C.R. 213, at para. 85, legal measures to protect the environment "relate to a public purpose of superordinate importance". In Friends of the Oldman River Society v. Canada (Minister of Transport), [1992] 1 S.C.R. 3, the Court declared, at p. 16, that "[t]he protection of the environment has become one of the major challenges of our time." In Ontario v. Canadian Pacific Ltd.,

$48 \quad$ See $M G A$, supra note 1 , ss 7-11, especially s 9. Ibid, s 12:

A bylaw of a municipality applies only inside its boundaries unless

(a) one municipality agrees with another municipality that a bylaw passed by one municipality has effect inside the boundaries of the other municipality and the council of each municipality passes a bylaw approving the agreement, or

(b) this or any other enactment says that the bylaw applies outside the boundaries of the municipality.

Municipalities have no jurisdiction to regulate or control land use on provincially or federally owned lands.

50 2004 SCC 38, [2004] 2 SCR 74. 
[1995] 2 S.C.R. 1031, "stewardship of the natural environment" was described as a fundamental value (para. 55 (emphasis deleted)).

If justice is to be done to the environment, it will often fall to the Attorney General, invoking both statutory and common law remedies, to protect the public interest. ${ }^{51}$

The GOA does not grant citizens a substantive right to a clean and healthy environment, ${ }^{52}$ but does recognize and declare "the right of the individual to liberty, security of the person and enjoyment of property, and the right not to be deprived thereof except by due process of law." 53 The Alberta Bill of Rights requires that the MGA be interpreted so "as not to abrogate, abridge or infringe or to authorize the abrogation, abridgment or infringement" on that substantive right. ${ }^{54}$ Arguably, a declaration that security of the person and enjoyment of property are human rights is hollow if an individual does not have a corresponding right to live and enjoy property in a clean and healthy local environment. ${ }^{55}$ In Spraytech, the Supreme Court of Canada stated that "our common future, that of every Canadian community, depends on a healthy environment.... This Court has recognized that '[e]veryone is aware that individually and collectively, we are responsible for preserving the natural environment ... environmental protection [has] emerged as a fundamental value in Canadian society.",56

Before 1994, the GOA regulated how municipalities were to engage in land use planning and decision-making through the now-repealed Planning Act. ${ }^{57}$ Provisions of the Planning Act were rolled into the MGA as Part 17 and the Subdivision and Development Regulation. ${ }^{58}$ At that time, the old planning regime that required land use planning and development to be considered at a city-region ${ }^{59}$ scale ended abruptly. The GOA delegated authority for most

$51 \quad$ Ibid at paras 7-8.

See Jason Unger, Environmental Rights in Alberta: Module 1: Substantive Environmental Rights, (Edmonton: Environmental Law Centre, 2016) at 8, online: <elc.ab.ca/wp-content/uploads/2016/12/ EBR MOD-1 Substantive-Environmental-Rights-in-Alberta.pdf $>$ :

A substantive environment right may be viewed as both positive and negative in nature. An environmental right may be used to prohibit decisions that degrade the environment or it may be used to demand action by government or a third party to address activities or decisions which may result in harm. Typically our laws create an environmental regulatory system where high risk activities receive more oversight, with the aim of mitigating negative environmental impacts, and, theoretically at least, refusing to permit activities with "unacceptable" impacts on the environment.

See also Jason Unger, Environmental Rights in Alberta: A Right to a Healthy Environment: Module 3: Private Enforcement for Environmental Quality (Edmonton: Environmental Law Centre, 2016), online: <elc.ab.ca/wp-content/uploads/2016/12/EBR_Mod-3_-CitizenEnforcement.pdf>.

53 Alberta Bill of Rights, RSA 2000, c A-14, s 1(a).

$54 \quad$ Ibid, s 2: "[e]very law of Alberta shall, unless it is expressly declared by an Act of the Legislature that it operates notwithstanding the Alberta Bill of Rights, be so construed and applied as not to abrogate, abridge or infringe or to authorize the abrogation, abridgment or infringement of any of the rights or freedoms herein recognized and declared."

55 This argument is not further elaborated in this article, but see David R Boyd, The Right to a Healthy Environment: Revitalizing Canada's Constitution (Vancouver: UBC Press, 2012); David R Boyd, Cleaner, Greener, Healthier: A Prescription for Stronger Canadian Environmental Laws and Policies (Vancouver: UBC Press, 2015).

56 Spraytech, supra note 24 at para 1, citing Ontario v Canadian Pacific Ltd, [1995] 2 SCR 1031 at para 55.

RSA 1980, c P-9, as repealed by Municipal Government Act, SA 1994, c M-26.1.

Alta Reg 43/2002.

For a description of city-regions, see Leonore Evans, Moving Towards Sustainability: City-Regions and Their Infrastructure (Ottawa: Canadian Policy Research Networks, 2007). For the purposes of planning under the old Planning Act, supra note 57, Alberta's city-regions included the Calgary Metropolitan Area, the Edmonton Metropolitan Area, and so on. 
land use planning and development on private land ${ }^{60}$ to local governments "to achieve the orderly, economical and beneficial development, use of land and patterns of human settlement, and ... to maintain and improve the quality of the physical environment within which patterns of human settlement are situated in Alberta." ${ }^{\prime \prime}$ What constituted an "improvement" or the "physical environment" was not defined. Generally, improvements introduced some human intervention into the physical environment in the form of developments $^{62}$ (which by definition included buildings) which were subject to municipal taxation. Maintaining and improving the physical environment did not translate into sustainable development practices where economic, social, and environmental impacts on the landscape or community were balanced during land use decision-making processes. The impacts of physical improvements often resulted in the elimination of vast tracts of agricultural lands and environmentally significant areas during stripping and grading activities that prepared the lands for development, for example, encroachments on riparian lands in river corridors, and filling in of wetlands and complex ravine systems.

The LUPS were adopted by the Province in 1996, and section 622 of the MGA was enacted, requiring that all municipal land use decision-making be consistent with the LUPS. Through the LUPS, the Province "encouraged" municipalities to minimize and mitigate any local negative impacts on provincially owned "natural resources" and "water resources" during subdivision and development of private lands. ${ }^{63}$ While the LUPS were not mandatory, all municipal decision-makers were required to ensure that their planning documents and decisions made under Part 17 were consistent with those provincial policies. Consistency was not defined.

In the MGA, municipal land use planning and development processes were to be local in nature, and did not need to reflect regional scale land use considerations, although municipalities were encouraged to adopt Intermunicipal Development Plans to jointly plan for future growth and development by agreement with their adjacent neighbours. In the 2000 s, regional land use plans were introduced as regulations through the $A L S A$. The regions reflect the boundaries of Alberta's major watersheds, ${ }^{64}$ and are large land masses that embed many small interconnected social-ecological systems and city-regions.

$60 \quad$ Part 17 provides specific exemptions where municipal statutory policy documents and the land use bylaw would not apply, even on private lands. These exemptions are for land uses where the provincial or federal governments already have legislation in place to regulate those land uses, such as pipelines, oil and gas, and livestock operations. See MGA, supra note 1, ss 618-20. But see Northland Material Handling Inc v Parkland (County), 2012 ABQB 407, 100 MPLR (4th) 277 at para 47 [Northland], where the Alberta Court of Queen's Bench clarified that compared to section 619 of the MGA, 620 does not give any kind of precedence or paramountcy to Alberta Environment permits over municipal land use bylaws and other decisions:

Turning first to the MGA, it is noteworthy that there are key differences between s. 619(1), which deals with certain types of permits and approvals, and s. 620, which deals with Alberta

Environment permits and approvals. Although NRCB permits and approvals, for example, clearly prevail over development decisions, permits and approvals of agencies such as Alberta Environment only prevail over any condition of a development permit that conflicts with the permit or approval. The Legislature clearly intended to make a distinction between environmental legislation on the one hand, and certain other types of regulation on the other. Therefore, the task here is to determine if the Council's decision to deny an extension contains a condition that conflicts with Alberta Environment's approval [emphasis added].

MGA, ibid, s 617.

Ibid, s 616(b).

LUPS, supra note 40 at 7-11. In these parts, the GOA described the environmentally significant features and water resources that municipalities were encouraged to enhance or protect during land use development and subdivision processes.

64 Alberta has seven major river basins: see Water Act, supra note 7, s 1(1)(ff). 
Generally, the MGA has been interpreted broadly and generously in support of municipal decision-making discretion. ${ }^{65}$ However, Part 17 has been interpreted as restrictive legislation, and does not include provisions that specifically empower municipal councils to manage surface water resources or air quality. Before 2015, the only enabling provisions in Part 17 that addressed the environment were section 664 that enabled the dedication of specifically described lands as "environmental reserves" to the municipality during subdivision processes (under certain circumstances), and section 640(4) that enabled a municipal council to determine building setbacks from low lying areas, lands subject to flooding, and a number of listed types of water bodies. ${ }^{66}$ Environmental considerations during land use planning were often restricted to determining whether a parcel of land proposed for subdivision or development was suitable for the intended purpose because the lands may have been subject to flooding, slumping, or subsidence post-development. Environmental considerations are, therefore, more concerned with how hazardous lands may impact human development and buildings, than on how the environment may be impacted during and post-development.

Part 17 also included section 632(3)(b)(iii), whereby a municipality was given discretionary authority to address "environmental matters within the municipality" in a municipal development plan (MDP). ${ }^{67}$ An MDP is a high-level planning policy document whereby a municipality addresses future growth and development patterns, and proposes and identifies locations for major infrastructure, transportation systems, and other municipal services and facilities. Many municipalities do include high-level policy statements about environmental matters in their MDPs; however, these policy statements are not required to be translated into land use bylaw provisions. Land use bylaws are the means whereby statutory plans like the MDP are put into action. ${ }^{6}$ Municipalities are not required to undertake any of the proposals or projects identified in an MDP ${ }^{69}$ However, section 638 of

65 The MGA must be given a broad and purposive interpretation: see e.g. United Taxi Drivers' Fellowship of Southern Alberta v Calgary (City), 2004 SCC 19, [2004] 1 SCR 485. See also Northland, supra note 60 at paras 3, 33:

When reviewing the decisions of an elected municipal council, unelected courts must respect the limits of their role in a democracy: to interfere in the decisions of an elected council only to the extent necessary to uphold constitutional values and statutory limitations: Catalyst Paper Corp. Courts must limit their review to ensuring that the municipal council acted legally and reasonably... The common law has a long history of wide deference to elected municipal councils in recognition of their role in a democracy. This deference recognizes, in part, the different roles attributed in a democracy to elected decision makers and unelected judges. This deference, wide and strong as it is, nonetheless applies only to the actions of a council taken within authority. The role of courts on judicial review of decisions of municipal councils is, first, to ensure that the council acted legally, i.e. within the authority granted to it.

See also Interpretation Act, RSA 2000, c I-8, s 10: "[a]n enactment shall be construed as being remedial, and shall be given the fair, large and liberal construction and interpretation that best ensures the attainment of its objects."

MGA, supra note 1, ss 640(4), 664.

Ibid, s 632(3)(b)(iii).

Hartel Holdings Co Ltd v City of Calgary, [1984] 1 SCR 337 at 352.

See Government of Alberta, MGA Review Discussion Paper: Statutory Plans and Planning Bylaws (Edmonton: GOA, 2013) at 7, online: $<$ https://www.mgareview.alberta.ca/wp-content/upLoads/media/ Statutory-Plans-and-Planning-Bylaws-Discussion-Paper.pdf $>$ :

Statutory plans are often applied hierarchically to reflect a range from general to specific. The $M G A$ requires statutory plans to be consistent with one another and with any regional plans adopted for the area under $A L S A$. However, other than the order in which statutory plans are listed within the MGA, there is no legislated hierarchy of statutory plans. The land use bylaw, the tool by which municipalities implement their statutory plans, is not required to align with the statutory plans. This flexibility allows municipalities the ability to exercise discretion and judgment in their land use decisions and operations. However, this flexibility may also create elements of uncertainty for decision-makers and, in some cases, may devalue the intended role of statutory plans (e.g. preservation of agricultural land policy within municipal development plan does not carry over into agricultural land use district subdivision rules within the land use bylaw).

See also ibid at 6: "[a]dditionally, the MGA states that a municipal council is not required to undertake 
the MGA stipulated that all statutory plans adopted by a municipality had to be consistent with each other, and section 638.1 further clarified that if there was an inconsistency between a statutory plan or the land use bylaw and a regional plan under ALSA, the ALSA regional plan (such as SSRP or $L A R P$ ) prevailed to the extent of the inconsistency. ${ }^{70}$

In Part 3 of the MGA, subject to any other enactment, section 60 provided municipalities with special bylaw-passing powers for the "direction, control and management of the bodies of water within the municipality, including the air space above and the ground below," excepting out mines and minerals. ${ }^{71}$ However, section 60 was not generally relied upon by municipal councils to manage local water bodies, although the benefits of a section 60 water body management bylaw and plan have been raised in the past. ${ }^{72}$

As mentioned above, section 7 of the MGA provided general jurisdiction to pass bylaws for municipal purposes to include those that would address the safety, health, and welfare of people, and the protection of people and property, and this provision was often relied upon by councils to pass bylaws for environmental purposes, such as to curb the use of cosmetic pesticide application, to protect receiving water bodies from pollution by phosphorus or nitrogen, or to discourage idling of motor vehicles to improve air quality within municipal boundaries. Section 7(h) provided municipalities with the authority to pass bylaws for a municipal purpose respecting "wild and domestic animals and activities in relation to them," 73 notwithstanding that wild animals are regulated and controlled through other provincial laws.

Until 2015, the MGA was amended from time to time without any major changes to any of the provisions discussed above and most municipal councils were reluctant to manage the environment at a local scale, often citing lack of jurisdiction as one of the reasons. ${ }^{74}$ According to many municipalities, federal laws and provincial laws, such as the EPEA, the Water Act, and the Public Lands Act, ${ }^{75}$ already addressed all matters pertaining to managing the environment and there were no aspects of the environment that municipalities were empowered or responsible to manage at the local or regional scales.

While the province recognized the important role played by municipal governments in environmental governance at the local scale, other than section 60 with respect to water bodies, there were no special provisions that required a municipal council to manage any component of the environment except for privately owned land, at least not as management was explained earlier in this article. However, the LUPS, ALSA, and regional plans, such as the SSRP, did set out the province's expectations that municipalities were to manage use of private lands within their boundaries to keep the state of identified natural resources within desirable bounds as established in regional plans.

any of the projects that are identified in statutory plans, which has resulted in some to question the purpose of having statutory plans"; MGA, supra note 1, s 637: "[t]he adoption by a council of a statutory plan does not require the municipality to undertake any of the projects referred to in it." MGA, ibid, ss 638-638.1.

Ibid, s 60 .

See Judy Stewart, "Municipal 'Direction, Control and Management' of Local Wetlands and Associated Riparian Lands: Section 60 of Alberta's Municipal Government Act" (2009) 47:1 Alta L Rev 73 [Stewart, "Direction, Control and Management"].

MGA, supra note $1, \mathrm{~s} 7(\mathrm{~h})$.

Stewart, Reflexive Legal Framework, supra note 5.

RSA 2000, c P-40 [PLA]. 
Undoubtedly, municipalities already do play a significant role with respect to managing surface water resources located within municipal boundaries: for example, they manage municipal and regional systems for water diversion and treatment for potable water needs, wastewater treatment and discharge, and storm drainage management. All these systems are regulated and controlled by the GOA through provincial laws, such as the EPEA and the Water Act, but municipalities are required to finance and manage these systems on a local basis or through regional services commissions. ${ }^{76}$ Municipalities are also empowered to regulate and control land use and the development of riparian lands adjacent to water bodies. After subdivision processes, private lands dedicated to a municipality as environmental reserves are subsequently owned and managed by the municipality.

Some delegated authority for municipal management of local surface water resources did exist in the MGA pre-amendment; however, municipal management of local air quality is still not mentioned anywhere in the $M G A$. Also, there was no pre-amendment delegated authority for municipalities to work together to manage surface water resources or air quality at the regional landscape scale. Notwithstanding this lack of authority, the SSRP does require municipal decision-makers to comply with the regional land use plan and participate in management responses provided in the Air Quality Management Framework ${ }^{77}$ and Surface Water Quality Management Framework. ${ }^{78}$

Although clear delegated authority was lacking regarding whether the MGA granted municipalities the power to manage surface water resources and air quality at the local scale, or through collective action at the regional scale pre-amendment, some municipal councils have passed bylaws to that effect since $1994 .^{79}$ The remainder of this article examines and analyzes whether recent amendments to the MGA have provided such a legislative scheme.

\section{OVERVIEW OF RECENT AMENDMENTS to THE MGA}

As social-ecological systems became more complex throughout Alberta as a result of population and economic growth, the GOA recognized that land use and water management needed to be integrated at the watershed scale. ${ }^{80}$ Municipal collaboration was required to address many growth-related transboundary and transjuridictional social, economic, and environmental issues arising at the city-region scale where no provincial or municipal law existed to address growth.

In 2013, the MGA was amended, adding Part 17.1, and enabling two or more participating municipalities to voluntarily form a growth management board (GMB). In 2015, city charter legislation was introduced in Part 4.1, empowering Edmonton and Calgary to create city charters. Arguably, both of these significant amendments opened debate about whether municipalities were empowered to manage the environment at the local, city, or regional scales.

MGA, supra note 1, Part 15.1.

Supra note 42.

Supra note 41.

For example, the City of Calgary lists many bylaws that regulate and control human interactions in the environment as discussed in this article, such as bylaws for community standards including nuisances, drainage, storage and transportation of dangerous goods, wastewater, and so on. See City of Calgary, "Bylaws," online: <www.calgary.ca/CA/city-clerks/Pages/Legislative-services/Bylaws.aspx>. 
During 2016 and 2017, through provisions in the MMGA, the GOA enacted a Preamble plus two new purposes of municipal government: "to work collaboratively with neighbouring municipalities to plan, deliver and fund intermunicipal services," being of the environment." 82 The MMGA also provided a new definition of what constitutes a "body of water" which affects section 60, and several provisions in Part 17. The MMGA significantly changed the "environmental reserve" provisions, and added the ability for municipal councils to pay market value for "conservation reserves" during the subdivision process. The provisions for intermunicipal development plans (IDPs) were amended, making it mandatory that adjacent municipalities address environmental matters within the IDP area, either generally or specifically. New legislation was provided in Part 17.2 for mandatory intermunicipal collaboration to provide transboundary and transjurisdictional infrastructure and regional scale servicing. These amendments are each discussed below.

\section{Growth MANAGEMENT BoARdS}

GMBs were originally intended to be voluntary associations of two or more participating municipalities now empowered "to provide for integrated and strategic planning for future growth in those municipalities." $" 83$ What the GOA intended by "integrated planning for growth" is left open to interpretation. The main function of a GMB was to prepare a growth plan to provide direction for the future activities of municipal councils in participating municipalities. ${ }^{84}$ The lands within the boundaries of participating municipalities were considered the "growth region" for planning purposes.

When the GOA introduced the concept of GMBs in 2013, it provided enabling provisions that did two things. First, the new legislation recognized the value of collective action. Second, provisions steered and guided the formation of GMBs according to legally acceptable standards, while giving legislative effect to co-created growth plans that would emerge. The legislation defined terms like growth management boards, growth plans, growth regions, participating municipalities, and municipal agreements under the legislative scheme, providing a framework for common discourse, and a standardization of voluntary collective action to address growth management issues at a regional landscape scale.

\footnotetext{
81 Supra note 4, s 6. Most of the MMGA amendments came into force on 1 January 2018.

MGA, supra note $1, \mathrm{~s} 3$. For the history of consultations leading up to enactment of the MMGA, see Alberta, Legislative Assembly, Hansard, 29th Leg, 3rd Sess (20 April 2017) at 691-700, online: <www.assembly.ab.ca/ISYS/LADDAR_files/docs/hansards/han/legislature_29/session_3/2017 0420_0900_01_han.pdf>.

$83 \quad M G A, i b i d, \overline{\mathrm{s}} 708.011$ : "[t] $\mathrm{t}$ he purposes of this Part are ... to enable 2 or more municipalities to initiate, on a voluntary basis, the establishment of a growth management board ... to provide for integrated and strategic planning for future growth in municipalities" [emphasis added]. Integrated planning is not defined. The MMGA amended this section and a mandated Calgary Growth Management Board [Calgary GMB] was appointed by the GOA. Part 17.1 does not provide provincial direction as to whether a GMB is empowered to manage the environment or natural resources at a regional scale, but see Calgary Metropolitan Region Board Regulation, Alta Reg 190/2017, s 3(1)(c) [Calgary Regulation], stipulating that the growth management board will "ensure environmentally responsible land-use planning, growth management and efficient use of land." The regulation also sets out the objectives of the board that include ensuring a healthy environment and promoting environmental well-being and competitiveness (Calgary Regulation, ibid, s 8). The GOA provides that a growth plan created by the board must include policies regarding environmentally sensitive areas (Calgary Regulation, ibid, s 9(1)(d)). One of the objectives of the servicing plan to be created by the board is "to facilitate orderly, economical and environmentally responsible growth in the Calgary Metropolitan Region" (Calgary Regulation, ibid, s 15(c)).

$84 \quad$ See MGA, ibid, s 708.12(1).
} 
GMBs were to be established through regulations, and the Lieutenant Governor in Council would have the final say in their establishment and the content of growth plans. Section 708.02(2) of the MGA provided what must be included in a regulation that established a GMB, and section 708.02(3) listed what may be included. ${ }^{85}$ The list of discretionary matters that might be included in a growth plan was broadly stated: for example, the mandate of the GMB, the objectives and contents of a growth plan, and the effect of the growth plan were all discretionary matters. As well, originally, the Lieutenant Governor in Council could direct that any other matter be included in a growth plan to carry out the purpose of Part 17.1.

While management of the environment within the growth region was not specifically listed as a matter to be included in a growth plan, there was nothing restricting participating municipalities from collaborating to manage the cumulative effects of growth on components of the environment within the growth region, such as surface water resources and air quality. ${ }^{86}$ Furthermore, section 708.06 provided that a GMB must act in accordance with any applicable $A L S A$ regional plan. For example, the SSRP provides clear expectations for municipal participation in a number of strategies to sustain the desired state of components of the environment at the watershed scale.

Originally, the mandate of a GMB was a discretionary matter to be determined by participating municipalities. Municipalities were not compelled to form GMBs with their neighbours, or to become participating municipalities, or to enter into municipal growth management agreements. Instead, the legislation enabled and supported voluntary network formation and co-creation of knowledge and plans to manage growth through volunteerism. Arguably, the legislation effectively enabled voluntary networking and collective action, and integrated and strategic planning for future growth were enshrined as worthwhile pursuits by municipal networks that were already collaborating voluntarily to problem-solve and achieve a shared public purpose. Additionally, the original legislation provided that GMBs could develop policy at the growth region scale, but each participating municipality would have discretion to interpret and implement policies according to local capacity and resources.

The Calgary Regional Partnership (CRP), now defunct, was an example of a voluntary grassroots organization that evolved over time to address gaps in provincial regulation and municipal bylaws for managing the impacts of growth on communities, the economy, and the environment at a regional landscape scale. The Calgary city-region is a dynamic, complex social-ecological system where the people and the ecosystem are inextricably connected through transportation corridors, trade centres, irrigation districts, shared waterways, or unique landscape features that everyone depends on for life support, quality of life, or economic prosperity. The CRP was a voluntary network of municipal governments who chose to take collective action to address growth through shared issue identification and co-creation of a regional growth management plan at a scale where no provincial legislation

\footnotetext{
${ }_{85} \quad$ Ibid, ss 708.02(2)-(3).

$86 \quad$ Ibid, s 708.12(1):

that conflict or are inconsistent with a growth plan:

(a) undertake a public work, improvement, structure or other thing;

(b) adopt a statutory plan;

(c) make a bylaw or pass a resolution;

(d) enter into a municipal agreement.
}

Despite any other enactment, no participating municipality shall take any of the following actions

A GMB is empowered to order a participating municipality to stop such an action, and to enforce growth plan provisions through a Court of Queen's Bench application for injunction or other relief. 
or municipal bylaws were in effect to manage growth. In the Calgary city-region, the scarcity of water to support rapid population and economic growth was the driving force behind voluntary collective action. The Calgary Metropolitan Plan ${ }^{87}$ was achieved by consensus among CRP members and was an example of an adaptive co-management plan whereby all the municipalities that helped create the plan had a role and responsibility to implement the plan within their own local boundaries. The mantra of the CRP was "thinking regionally but acting locally." 88

The original GMB provisions seemed to provide bridging legislation to ensure that organizations such as the CRP had new mechanisms for legal constitution under Alberta laws - municipalities no longer had to rely on inappropriate legislation to become legal entities in order to achieve their public purposes. They now had specialized enabling provisions designed with municipalities in mind, to help them frame their public purpose and meet their collective objectives. GMBs would be corporations, much like municipalities are corporations, with distinct mechanisms for appointing representatives and reporting on their activities at regular intervals.

The powers and responsibilities of GMBs were clearly set out to enable collective action and to manage growth in accordance with the rule of law in Alberta. The most important aspect of the new provisions was that the co-created growth plans would now have legal effect in the municipalities, and only in those municipalities that were participating municipalities in the co-creation of the plan. Arguably, the GOA recognized that a growth plan was co-created by municipalities through relationship building, trust, consensus building, and trade-offs, representing years of collective hard work to achieve something all participating municipalities agreed to in principle and in application.

Integrated and strategic planning for future growth requires land use management planning and strategies to sustain or improve the environment during periods of growth. Local environmental management programs to sustain or improve local water resources or air quality are part of a nested and comprehensive cumulative effects management system designed at the watershed scale. In the SSRP land use region, this desired outcome is presented in both the Surface Water Quality Management Framework and the Air Quality Management Framework. Local level management programs and bylaws to sustain or improve surface water resources and air quality are recognized as having an effect on the social-ecological system at the growth region scale, nested within the IRMS at the watershed scale.

In 2016, Part 17.1 was amended through provisions in the MMGA, and the purpose and voluntary nature of GMBs were significantly changed. These more recent amendments may limit the ability of a GMB to address environmental management issues at the growth region scale because the new provisions are inherently more prescriptive. For example, the amended purpose statement in section 708.011 of the MGA now reads, as follows: "[t]he purposes of this Part are (a) subject to clause (b), to enable 2 or more municipalities to initiate, on a voluntary basis, the establishment of a growth management board, and (b) to establish 
growth management boards for the Edmonton and Calgary regions to provide for integrated and strategic planning for future growth in municipalities." $" 89$

In addition, section 708.02(2) was substantively changed. The regulation establishing a GMB now must

(d) require the growth management board to prepare a growth plan for the growth region,

(e) specify the objectives of the growth plan,

(f) specify the contents of the growth plan,

(g) specify the timelines for completing the growth plan,

(h) specify the form of the growth plan,

(i) specify the desired effect of the growth plan,

(j) specify regional services and the funding of those services, and

(k) specify the process for establishing or amending the growth plan. ${ }^{90}$

Most of these matters were previously discretionary matters, as discussed above.

This amendment to Part 17.1 of the MGA clarifies that the objectives of a growth plan and the contents of a growth plan will be established by regulation, and amendments to a growth plan will need to conform to a regulated process.

In the Calgary Regulation, ${ }^{91}$ which was enacted while this article was being written, the GOA mandated that the growth plan for the Calgary Metropolitan Region must include "policies regarding environmentally sensitive areas" and the specific actions to be taken by the participating municipalities to implement that aspect of the growth plan. ${ }^{92}$ However, there is no mandatory requirement that transboundary and transjurisdictional environmental management systems that affect all the participating municipalities be addressed in a growth plan. The regulation does clarify that environmental health in the region is important. For example, two of the objectives of the Calgary Metropolitan Region's growth plan are "to coordinate decisions in the Calgary Metropolitan Region to sustain economic growth and ensure strong communities and a healthy environment," and "to promote the social, environmental and economic well-being and competitiveness of the Calgary Metropolitan Region." 93

There may be opportunities for the newly mandated GMB for the Calgary Metropolitan Area to address environmental management as part of the mandate of the $\mathrm{GMB}^{94}$ as well as discretionary matters. ${ }^{95}$ The GMB amendments provide some clarity that municipalities have some jurisdiction to manage some components of the environment at the growth region scale, such as "environmentally sensitive areas." These same landscapes are referred to in other amendments as "environmentally significant features," as explained below.

MGA, supra note $1, \mathrm{~s} 708.011$.

Ibid, s 708.02(2).

Calgary Regulation, supra note 83, s 9(1)(d).

Ibid, s 9.

Ibid, s 8.

See MGA, supra note 1, s 708.02(3)(d), where the regulation establishing a GMB may deal with "the mandate of the growth management board."

Calgary Regulation, supra note 83, s 9(2): "[i]n preparing a proposed Growth Plan, the Board may also have regard to any matter relating to the physical, social or economic development of the Calgary Metropolitan Region." 


\section{City Charters}

Part 4.1 of the MGA, enabling the creation of city charters, was enacted in 2015 . The stated purpose of the city charter provisions "is to authorize the establishment of charters to address the evolving needs, responsibilities and capabilities of cities in a manner that best meets the needs of their communities." ${ }^{.96}$ Edmonton and Calgary are the focus of the city charter provisions; however, neither has created a proposal for a city charter to be submitted to the GOA as of June 2018.

Section 141.3 provides broad enabling legislation such that, on request by a city, the Lieutenant Governor in Council may establish a charter for that city by regulation. ${ }^{97}$ There are some procedural provisions, for example, the requirement that "[b]efore a charter is established or amended ... the proposed charter or amendment [must be] published on the Minister's department's website for at least 60 days."98 Public notice and a public hearing are also required before a city council may give third reading of a bylaw for a proposed charter. The elements of a city charter are described in section 141.5 below:

\section{Elements of charter}

141.5(1) Subject to this Part, a charter governs all matters related to the administration and governance of the charter city, including, without limitation, the powers, duties and functions of the charter city and any other matter that the Lieutenant Governor in Council considers desirable.

In subsection (3), a reference to "this Act" does not include this Part or Part 15.1 or 17.1.

A charter may do one or more of the following:

(a) provide that a provision of this Act or any other enactment does not apply to the charter city or applies to the charter city with the modifications set out in the charter;

(b) specify or set out provisions that apply in respect of the charter city in addition to, or instead of, a provision of this Act or any other enactment;

(c) authorize the charter city to modify or replace, by bylaw, a provision of this Act or any other enactment, with respect to the charter city, to the extent set out in the charter.

(4) Before giving second reading to a proposed bylaw referred to in subsection (3)(c), the council of the charter city must hold a public hearing with respect to the proposed bylaw in accordance with section 230 after giving notice of it in accordance with section 606.

(5) A charter may include provisions respecting its interpretation.

(6)

A charter may generally provide for any other matter necessary for the purposes of giving effect to this Part.

MGA, supra note 1, s 141.2. From August 2017 to October 2017, the public were again invited to provide feedback on a draft city charter regulation: see Municipal Government Act, City of Charter, 2018 Regulation, online: Alberta Municipal Affairs <www.municipalaffairs.alberta.ca/ documents/draft-city-charters-regulation.pdf $>$ [Draft City Charter Regulation]. See section 4(2)(a) of the proposed regulation, whereby the GOA clearly authorizes city management of components of the environment through general jurisdiction to pass bylaws. 
Except to the extent that a charter or a bylaw made pursuant to subsection (3)(c) provides otherwise, this Act and any other enactment apply to the charter city. ${ }^{99}$

Section 141.6 of the MGA clarifies that, "[e]xcept to the extent that this Part provides otherwise, if there is a conflict or inconsistency between a charter or a bylaw made pursuant to section 141.5(3)(c) and a provision of this Act or any other enactment, the charter or bylaw prevails to the extent of the conflict or inconsistency." 100 Unless a city charter provides otherwise, the rights and obligations of a city are not affected by the establishment of a charter for that city, and the rights of the Crown in right of Alberta are not affected by the establishment of a charter. However, a city charter may include provisions that do affect the rights and obligations of the city, and the rights of the Crown. ${ }^{101}$ It is noteworthy that, unlike other enabling legislation in the MGA, or the MMGA, the city charter provisions do not include a requirement that city charters be consistent with $A L S A$ regional plans.

According to an overview package produced by the GOA in early 2017 as part of a public consultation process: "City Charters will encourage Calgary and Edmonton to respond to environmental pressures with local solutions, including measures that provide greater community energy security, climate change mitigation and adaptation planning, and protection of the local physical environment."102

The draft regulation for city charters that was presented for public comment between August and October $2017,{ }^{103}$ clearly delegated authority to both cities to pass local bylaws to manage components of the environment. It proposed that the following items be added to the cities' general jurisdiction to pass bylaws under section 7 of the MGA:

[T]he well-being of the environment, including bylaws providing for the creation, implementation and management of programs respecting any or all of the following:

(i) contaminated, vacant, derelict or under-utilized sites;

(ii) climate change adaptation and greenhouse gas emission reduction;

(iii) environmental conservation and stewardship;

(iv) the protection of biodiversity and habitat;

Ibid, 141.5 [emphasis added].

Ibid, s 141.6.

Ibid, s 141.9 .

Government of Alberta, City Charters: Overview Package (Edmonton: GOA, 2016), online: <https:// www.alberta.ca/documents/City-Charters-Overview-Package.pdf $>$ at 16 . Note also the statements at 18:

The cities plan at a large scale, and transform entire landscapes within municipal boundaries. City charters will provide the cities with tools to protect environmentally significant areas, and protect the local natural environment through land-use planning and waste reduction. More specifically, these proposals will recognize the environment as a general purpose for the two cities, elevating their role as environmental stewards and supporting healthy, sustainable communities in which citizens can interact with the natural and built environments.

See Draft City Charter Regulation, supra note 96. 
(v) the conservation and efficient use of energy;

(vi) waste reduction, diversion, recycling and management. ${ }^{104}$

The city charter provisions in the $M G A$, and the proposed regulations, authorize Edmonton and Calgary to manage the environment within city boundaries. The Draft City Charter Regulation does not propose to affect the rights of the Crown in right of Alberta with respect to legislation such as the Water Act and the PLA. ${ }^{105}$

\section{THE MMGA AND AN ACT TO STRENGTHEN MUNICIPAL GOVERNMENT ${ }^{106}$}

In the context of the GOA's amendments to modernize municipal governance in the province, the MMGA and subsequent amendments since 2016 create a legislative scheme that authorizes municipalities to manage the environment. In order to understand the intent of the GOA with respect to each of these amendments, it is imperative to examine the amendments in the context of the overall MGA review. In a recent 2016 decision, Thomas v. Edmonton (City), ${ }^{107}$ Chief Justice Fraser speaking for the Alberta Court of Appeal, summed up the contextual approach to interpreting legislation, such as the MMGA, as follows:

[19] The Act must be read in its entire context, in its grammatical and ordinary sense and in harmony with the legislative scheme, its object and the intention of the legislature: Rizzo \& Rizzo Shoes Ltd. (Re), [1998] 1 SCR 27 at para 21. This approach, often referred to as a purposive and contextual analysis, also applies to the interpretation of municipal bylaws: United Taxi Drivers' Fellowship of Southern Alberta v Calgary(City), 2004 SCC 19 at para 8, [2004] 1 SCR 485. Since bylaws are passed by duly elected municipal councillors in the exercise of their power to enact delegated legislation, this function is a legislative one involving a number of social, economic, political and other non-legal considerations: Catalyst Paper Corp. $v$ North Cowichan (District), 2012 SCC 2 at para 19, [2012] 1 SCR 5.

[20] The goal of this purposive and contextual analysis has been summed up this way. "[S]tatutory interpretation is the art of finding the legislative spirit embodied in enactments": Bristol-Myers Squibb Co. $v$ Canada (Attorney General), 2005 SCC 26 at para 102, [2005] 1 SCR 533 (per Bastarache J, dissenting). A court is required to assess legislation in light of its purpose since legislative intent, the object of the interpretive exercise, is directly linked to legislative purpose. As a result, as explained in Ruth Sullivan, Sullivan on the Construction of Statutes, 6th ed (Markham: LexisNexis, 2014) [Sullivan] at 259:

In so far as the language of the text permits, interpretations that are consistent with or promote legislative purpose should be adopted, while interpretations that defeat or undermine legislative purpose should be avoided.

[21] A contextual approach rests on a simple, yet compelling, foundation. What words mean depends on the entire context in which they have been used. Since all words in a statute take their colour from their surroundings, a court is obliged to consider the total context of the provisions to be interpreted: see Chieu $v$ Canada (Minister of Citizenship and Immigration), 2002 SCC 3 at para 34, [2002] 1 SCR 84; Bell ExpressVu 
Limited Partnership $v$ Rex, 2002 SCC 42 at para 27, [2002] 2 SCR 559. Therefore, any attempt to deduce legislative intent behind a challenged word or phrase cannot be undertaken in a vacuum. As Baroness Hale observed in Stack v Dowden, [2007] UKHL 17 at para 69: "In law, context is everything".

[22] In summary, statutory construction is ultimately a search for the intention of the legislator. That search requires consideration of the specific words in question, the scheme, purpose and structure of the part of the enactment in which the words are found, along with other legislation (including delegated legislation) touching a similar or related matter. In that way, the overall objective of the specific enactment is identified and fulfilled. ${ }^{108}$

What follows is a review of the specific amendments in the MMGA, and the subsequent An Act to Strengthen, and an interpretation of how the specific amendments create a statutory or legislative scheme that authorizes municipal management of the environment, specifically surface water resources and air quality. As stated by the Supreme Court of Canada in ATCO Gas and Pipelines Ltd. v. Alberta (Energy and Utilities Board), "the powers conferred by an enabling statute are construed to include not only those expressly granted but also, by implication, all powers which are practically necessary for the accomplishment of the object intended to be secured by the statutory regime created by the legislature."

\section{A. The Preamble of The MMGa}

In the second "Whereas" statement of the MMGA's Preamble, the GOA recognized the important role played by municipalities in Alberta's economic, environmental, and social prosperity today and in the future, or in other words, Alberta's sustainability. ${ }^{110}$ However, "environmental prosperity" is not defined in the $M M G A$, nor is any process provided to help a municipal council balance economic, social, and environmental considerations during decision-making processes:

WHEREAS Alberta's municipalities, governed by democratically elected officials, are established by the Province, and are empowered to provide responsible and accountable local governance in order to create and sustain safe and viable communities;

WHEREAS Alberta's municipalities play an important role in Alberta's economic, environmental and social prosperity today and in the future;

WHEREAS the Government of Alberta recognizes the importance of working together with Alberta's municipalities in a spirit of partnership to co-operatively and collaboratively advance the interests of Albertans generally; and

WHEREAS the Government of Alberta recognizes that Alberta's municipalities have varying interests and capacity levels that require flexible approaches to support local, intermunicipal and regional needs. ${ }^{111}$

\footnotetext{
$108 \quad$ Ibid at paras 19-22.

1092006 SCC 4, [2006] 1 SCR 140 at para 51.

110 Sustainable development means: "development that meets the needs of the present without compromising the ability of future generations to meet their own needs." See Our Common Future, Chapter 2: Towards Sustainable Development, UNGAOR, 42nd Sess, Annex, Agenda Item 3, UN Doc A/42/427 (1987), online: United Nations <www.un-documents.net/ocf-02.htm>. MGA, supra note 1, Preamble [emphasis added].
} 
The wording is ambiguous. Section 12 of the Interpretation Act provides that the "preamble of an enactment is a part of the enactment intended to assist in explaining the enactment." "112 While the preamble may have an effect on how the MMGA is interpreted by the courts in the future, ${ }^{113}$ it does create an expectation that municipalities will play an important part with respect to environmental prosperity, or the environmental sustainability of municipalities throughout the province. However, the roles and responsibilities of municipalities in this regard are not clarified, and whether municipalities will be expected to play a role in environmental management is not determined through the preamble on its own, but may be imported by implication or by reading the preamble in the context of the other changes to the MGA.

\section{B. New Municipal Purposes in the MMGA AND AN ACT TO STRENGTHEN}

The MMGA and An Act to Strengthen provide two new purposes of municipal government that, arguably, provide legislative authority for municipalities to engage in environmental management activities at both the local and regional scales. The first new municipal purpose is "to work collaboratively with neighbouring municipalities to plan, deliver and fund intermunicipal services" 114 and the second is "to foster the well-being of the environment." 115 While the intent of the new purposes or the meaning of the terms used in the MMGA cannot be determined by reading Alberta Hansard transcripts of the debates about the MMGA and An Act to Strengthen, the debates do provide useful background context. ${ }^{116}$

\section{InTERMUnicipal COllaboration as A Municipal Purpose}

In 2016, the MMGA added a fourth municipal purpose: "to work collaboratively with neighbouring municipalities to plan, deliver and fund intermunicipal services." ${ }^{117}$ The $M M G A$

\section{Interpretation Act, supra note 65, s 12.}

113 See Kent Roach, "The Uses and Audiences of Preambles in Legislation" (2001) 47 McGill LJ 129, online: <www.lawjournal.mcgill.ca/userfiles/other/8178207-47.1.Roach.pdf $>$. See also Government of Alberta, "A User's Guide to Legislation," online: Alberta Justice and Solicitor General <https://www. justice.alberta.ca/programs_services/law/Pages/legislative_pubs.aspx>.

$114 \quad$ MMGA, supra note 4, s 6.

115 An Act to Strengthen, supra note 4, s 1(3). See also Alberta, Legislative Assembly, Hansard, 29th Leg, 3rd Sess (11 May 2017) at 999 (A Robert Turner), online: <www. assembly.ab.ca/ISYS/LADDAR files/docs/hansards/han/legislature 29/session 3/20170511 090001 han.pdf $>$ [Hansard]:

Don't municipalities already take environmental issues into consideration when making decisions?

Well, many do, but specifically enabling municipalities to consider environmental well-being will encourage them to take a leadership role in addressing this critical issue and will better position the municipalities as key partners with the government of Alberta in addressing environmental matters. Well, might this policy give municipalities a blank cheque to take land for environmental purposes? No. This wouldn't allow municipalities to adopt any policies or bylaws that are inconsistent with the provincial policy or legislation.

116 See Greater Vancouver Regional District v British Columbia (Attorney General), 2009 BCSC 577, 60 MPLR (4th) 98 at para 42:

In Upper Churchill the Court held, per McIntyre J., at p. 318: "I agree with the Court of Appeal in the present case that extrinsic evidence is admissible to show the background against which the legislation was enacted. I also agree that such evidence is not receivable as an aid to construction of the statute. However, I am also of the view that in constitutional cases, particularly where there are allegations of colourability, extrinsic evidence may be considered to ascertain not only the operation and effect of the impugned legislation but its true object and purpose as well. This was also the view of Dickson J. in the Reference re Residential Tenancies Act, 1979, supra, at p. 721, where he said: 'In my view a court may, in a proper case, require to be informed as to what the effect of the legislation will be. The object or purpose of the Act in question may also call for consideration though, generally speaking, speeches made in the Legislature at the time of enactment of the measure are inadmissible as having little evidential weight.", 
does not define intermunicipal services; however, they are often considered essential services, such as water and wastewater treatment facilities and distribution systems. The most interesting aspect of this new purpose is that municipalities will be required to work together to fund these services through local taxation or user fees. Traditionally, intermunicipal or regional servicing infrastructure was largely funded by the GOA.

It remains unclear whether intermunicipal services include facilities, services, programs, and activities to manage components of the environment on a local or intermunicipal scale. However, when the municipal purpose "to foster the well-being of the environment" was introduced through An Act to Strengthen, and other provisions in the MMGA that are discussed further below are interpreted as a comprehensive legislative scheme, it appears that municipalities have been granted such authority. This argument is supported by the MMGA provisions that introduce intermunicipal collaboration as a municipal purpose and Part 17.2, which is new legislation regarding the creation of institutional arrangements for intermunicipal collaboration. The Intermunicipal Collaboration Framework Regulation also supports such a scheme. ${ }^{118}$

The MMGA requires that, within two years of the legislation coming into force, two or more municipalities with common boundaries must create an "intermunicipal collaboration framework" (ICF) for three purposes: "a) to provide for the integrated and strategic planning, delivery and funding of intermunicipal services, (b) to steward scarce resources efficiently in providing local services, and (c) to ensure municipalities contribute funding to services that benefit their residents." 119 Resources are not defined, and may include surface water resources or other components of the environment by implication.

While local bylaws may be enacted and taxes levied to achieve the new municipal purpose, the GOA's regulatory scheme reflected in Part 17.2 standardizes and legitimizes intermunicipal service provisioning, even though these activities have been going on for decades in Alberta. Municipalities that adopt the ICF must align all of their bylaws, except their land use bylaws, with the ICF within 2 years. Section 5(2) of the ICF Regulation clarifies that once an ICF is adopted, if there is a conflict or inconsistency between a municipal bylaw and the ICF, the framework prevails.

Section 708.29(2) of the MMGA additions to the MGA does clarify what must be included in an ICF, as follows: "each framework must address services relating to (a) transportation, (b) water and wastewater, (c) solid waste, (d) emergency services, (e) recreation, and (f) any other services, where those services benefit residents in more than one of the municipalities that are parties to the framework." 120 Arguably, municipalities may provide surface water resource and air quality management programs and activities that are delivered at the intermunicipal scale for the benefit of their residents, pursuant to section $708.29(2)$ (f)), above. This argument is supported by two other legislative amendments provided in the MMGA, and the ICF Regulation under Part 17.2.

First, pursuant to the MMGA amendment to section 631(2)(a) of Part 17, municipalities that share common borders, that are not participating municipalities in a GMB must now

See Alta Reg 191/2017 [ICF Regulation].

MMGA, supra note 4, s 134 (adding section 708.27). See also Hansard, supra note 115. MMGA, ibid, s 134 . 
create an "intermunicipal development plan" (IDP) to address matters they consider necessary for those areas of land lying within the boundaries of the municipalities. ${ }^{121}$ The mandatory IDP must now address "environmental matters within the area, either generally or specifically."

Prior to enactment of the MMGA, municipalities were encouraged to enact IDPs by agreement with their adjacent neighbours, but there was no requirement for them to address environmental matters within the planning area. The mandatory requirement for adjacent municipalities to address environmental matters within the planning area reflects the GOA's intention that municipalities collaborate to manage environmental matters that are transboundary and transjurisdictional in nature, such as surface water resources and air quality.

Second, the ICF Regulation prescribes how municipalities are to create and amend an ICF and defines a "service" to include "any program, facility or infrastructure necessary to provide a service." 122 As discussed above, the GOA does recognize that municipalities play an integral role in IRMS, and as the preamble to the MMGA alludes, they also play a critical role in ensuring environmental prosperity and sustainability. Many municipalities regularly participate as members of environmental governance networks throughout Alberta, contributing resources to the networks' operations. For example, most municipalities that were members of the CRP in the Calgary city-region are also members of the Bow River Basin Council and the Calgary Region Airshed Zone. ${ }^{123}$ These voluntary multi-stakeholder organizations function as bridging organizations, bridging the gaps between local and provincial legislative schemes, and providing programs and services for watershed and airshed management at the intermunicipal and regional scales. ${ }^{124}$ Municipal members in these organizations actively participate in many of the environmental management activities and regional scale planning and monitoring programs. They voluntarily participate to co-create and implement regional scale watershed and airshed management plans through consensusbased decision-making processes. ${ }^{125}$

Arguably, the definition of a "service" in the proposed regulation is broad enough to include the programs, facilities, and infrastructure necessary to provide surface water resources, air quality, and other transboundary and interjurisdictional environmental management services, such as those provided through these organizations, as long as these services are included in the IDP by agreement among the municipal parties, or in an ICF that will subsequently be enacted as a regulation.

121 See ibid, s 97(b), stating that an IDP “(a) must address (i) the future land use within the area, (ii) the manner of and the proposals for future development in the area, (iii) the provision of transportation systems for the area, either generally or specifically, (iv) the co-ordination of intermunicipal programs relating to the physical, social and economic development of the area, $(v)$ environmental matters within the area, either generally or specifically, and (vi) any other matter related to the physical, social or economic development of the area that the councils consider necessary" [emphasis added]. ICF Regulation, supra note 118, s (1)(c).

See Stewart, Reflexive Legal Framework, supra note 5. Stewart researched the municipal environmental collaboration network in the Calgary Metropolitan Area that existed between 2014 and 2016 as part of a doctoral research program in the Faculty of Environmental Design at the University of Calgary. These statements are supported in the dissertation.

See ibid.

See ibid. 


\section{FOSTERING THE WELL-BEING OF THE ENVIRONMENT AS A Municipal PURPOSE}

Pursuant to recent amendments to the MGA through the MMGA and An Act to Strengthen, there are now five purposes of a municipality, as follows:

3 The purposes of a municipality are

(a) to provide good government,

(a.1) to foster the well-being of the environment,

(b) to provide services, facilities or other things that, in the opinion of council, are necessary or desirable for all or a part of the municipality,

(c) to develop and maintain safe and viable communities, and

(d) to work collaboratively with neighbouring municipalities to plan, deliver and fund intermunicipal services. $^{126}$

The GOA did not provide any interpretative guidance as to what a municipality must do "to foster the well-being of the environment." However, when construed in context of the preamble and other amendments, it might be implied that fostering the well-being of the environment includes managing the environment, and not necessarily only at the local scale. When construed in context of ALSA, regional land use plans, the new IDP provisions, and the draft regulation for growth management boards and city charters, a legislative scheme emerges that authorizes municipal management of the environment in order to foster environmental well-being.

Originally, in the discussion documents that were circulated to the public as part of province-wide consultations about An Act to Strengthen, the new purpose of a municipality was "stewardship of the environment," the majority of stakeholders who responded to the GOA's discussion document. ${ }^{128}$ While the public may understand what is involved in municipal environmental stewardship, ${ }^{129}$ they are not familiar with how a municipality will foster the well-being of the environment: the two phrases are not interchangeable. As discussed above, the GOA does not define the "environment," or provide any indication of what "well-being of the environment" means for the purposes of municipal government, or what actions a municipality might engage in to achieve or sustain environmental well-being.

Black's Law Dictionary defines "foster" as follows: "1. To give care to or promote the growth and development of (something or someone)... 2. To give aid or encouragement to; to sustain or promote." ${ }^{\prime 130}$ If municipalities are to foster the well-being of the environment in

\footnotetext{
126 MGA, supra note $1, \mathrm{~s} 3$ [emphasis added].

127 Government of Alberta, Municipal Government Act Review: What We Heard (Edmonton: Municipal Affairs, 2017) at 16, online: Alberta Municipal Affairs $<$ https://mgareview.alberta.ca/wp-content/up Loads/ media/WWH-Continuing-the-Conversation.pdf $>$. Ibid.

129 See Government of Alberta, "Environmental Stewardship,” online: Alberta Environment and Parks $<$ aep.alberta.ca/water/programs-and-services/water-for-life/partnerships/watershed-planning-andadvisory-councils/environmental-stewardship.aspx $>$ ("[e]nvironmental stewardship is defined as "the recognition of a collective responsibility to retain the quality and abundance of land, air, water and biodiversity, and to manage this natural capital in a way that conserves all of its environmental, economic, social and cultural values"). 
the context of the overall legislative scheme provided by the amendments to the MGA, it is reasonable that they are to manage components of the environment to sustain and promote environmental health. Whether components of the environment (or an ecosystem) are "healthy" is scientifically determinable: for example, the health of riparian landscapes adjacent to surface water bodies has been studied for several decades in Alberta. ${ }^{131}$

As discussed above, in order to interpret the new municipal purpose, a court would construe the new purpose as part of the statute, or a "harmonious whole." 132 Extrinsic evidence, such as transcription of debates in the Legislative Assembly as recorded in Alberta Hansard, could be relied upon as evidence of the GOA's intent in enacting the new purpose, and Alberta Hansard does provide some meaningful context. For example, when debating Bill 8 and the new municipal purpose in April 2017, Dr. Robert Turner, MLA for the Edmonton-Whitemud constituency had the following comments:

\begin{abstract}
Some stakeholders express concern that municipalities lack explicit authority to incorporate environmental well-being in their operational land-use decision-making processes. This may prevent municipalities from fully embracing a leadership role in environmental stewardship and more actively taking action towards the goal in Alberta's climate leadership plan. Members of the public are supportive of clarifying municipal responsibilities and consideration in the decision-making process that will lead to better planning and development decisions. Expanding municipal purpose in the MGA to include fostering environmental wellbeing will give municipalities a clear signal to consider the environment in a multitude of operational and growth decisions, and municipalities will not be able to pass bylaws that conflict with provincial legislation on these environmental measures. ${ }^{133}$
\end{abstract}

Dr. Turner's comments were echoed by other MLAs who had similar commentary about the value of adding this new purpose for municipal government. ${ }^{134}$ It is proposed that when interpreted along with other parts of a legislative scheme for modernized municipal government, this new municipal purpose supports Dr. Turner's commentary that municipalities are to consider the environment in a multitude of operational and growth decisions. According to the definition of management provided above in this article, considering the environment during decision-making and operational matters, or fostering the well-being of the environment, means to develop and manage implementation measures to keep the state of the environment within desired bounds established by the GOA in regional plans.

131 See Alberta Riparian Habitat Management Society, "Riparian Health Assessment," online: <cowsand fish.org/riparian/health.html>.

132 Canada Trustco Mortgage Co v Canada, 2005 SCC 54, [2005] 2 SCR 601 at para 10:

It has been long established as a matter of statutory interpretation that "the words of an Act are to be read in their entire context and in their grammatical and ordinary sense harmoniously with the scheme of the Act, the object of the Act, and the intention of Parliament": see 65302 British Columbia Ltd. v. Canada, [1999] 3 S.C.R. 804, at para. 50. The interpretation of a statutory provision must be made according to a textual, contextual and purposive analysis to find a meaning that is harmonious with the Act as a whole. When the words of a provision are precise and unequivocal, the ordinary meaning of the words play a dominant role in the interpretive process. On the other hand, where the words can support more than one reasonable meaning, the ordinary meaning of the words plays a lesser role. The relative effects of ordinary meaning, context and purpose on the interpretative process may vary, but in all cases the court must seek to read the provisions of an Act as a harmonious whole.

133 See Hansard, supra note 115 at 999 [emphasis added].

134 See ibid. The Hansard discussions captured the commentary of several MLAs with respect to the new purpose as proposed in An Act to Strengthen, supra note 4. 
The next three sections of this article highlight specific aspects of the MMGA and An Act to Strengthen that support the position that recent amendments to the MGA authorize municipalities to manage components of the environment within municipal boundaries, and through collective municipal action at a range of landscape scales.

\section{DEFINITION OF A BODY OF WATER}

Under MGA Part 17, municipalities are required to create land use districts for all lands located within their boundaries, ${ }^{135}$ and this includes lands and locations that are water bodies wherever found, even if they are man-made, temporary or seasonal water bodies, or water bodies with no discernible legal bank. According to the Water Act, "water bodies" are land locations where water is present, whether continuously, intermittently, or only during a flood. ${ }^{136}$ Similarly, the definition of wetlands refers to "land" where water is present. ${ }^{137}$

While municipalities are required to ensure that all lands in the municipality are included in a land use district, the inclusion of a definition of "body of water" in the MGA limits municipal jurisdiction to manage surface water bodies to only the bodies of water as defined in section 1(1.2) as follows: "[i]n this Act, a reference to a body of water is to be interpreted as a reference to (a) a permanent and naturally occurring water body, or (b) a naturally occurring river, stream, watercourse or lake." ${ }^{138}$

When engaging in land use planning and development under Part 17, Part 17.1, or Part 17.2, municipal jurisdiction to prohibit, or to regulate and control land use will be restricted to lands consisting of, or adjacent to, bodies of water as defined. Previously, pursuant to section 60 of the MGA, municipalities were granted "direction, control and management" of the rivers, streams, watercourses, lakes, and other natural bodies of water within the municipality, subject to any other enactment. ${ }^{139}$ The special power granted in section 60 was limited only to naturally occurring bodies of water, but they did not need to be permanent.

The new definition of "body of water" clarifies that municipal direction, control, and management under section 60 is limited to a subset of the water bodies as broadly defined in the Water Act. ${ }^{140}$ These are permanent and naturally occurring water bodies, and naturally occurring rivers, streams, watercourses, and lakes. The GOA may claim ownership of the beds and shores of this same subset of water bodies by operation of law. ${ }^{141}$ Section 3 of the PLA provides that "the title to the beds and shores of (a) all permanent and naturally occurring bodies of water, and (b) all naturally occurring rivers, streams, watercourses and

MGA, supra note 1 , ss $639,640(2)(a)$.

Water Act, supra note 7, s 1 (ggg).

Government of Alberta, Alberta Wetland Policy (Edmonton: GOA, 2013) at 4, online: Alberta Environment and Parks <aep.alberta.ca/water/programs-and-services/wetlands/documents/Alberta WetlandPolicy-Sep2013.pdf> ("[w] tetlands are land saturated with water long enough to promote formation of water altered soils, growth of water tolerant vegetation, and various kinds of biological activity that are adapted to the wet environment" [emphasis added]).

MGA, supra note $1, \mathrm{~s} 1(1.2)$.

Ibid, s 60. See also Stewart, "Direction, Control and Management," supra note 72.

See Water Act, supra note 7.

See PLA, supra note 75, s 3. See also Land Titles Act, RSA 2000, c L-4, s 61. 
lakes, is vested in the Crown in right of Alberta." 142 The GOA has limited municipal jurisdiction and intends municipalities to concern themselves with only this subset of water bodies in their decision-making processes as they exercise their authority.

Before the MMGA amendments, in day-to-day administration of the laws with respect to water bodies on both public and private lands in Alberta, bodies of water were interpreted to be a subset of water bodies (as defined in the Water Act ${ }^{143}$ with distinct features. ${ }^{144} \mathrm{~A}$ body of water was considered a water body with a bed and shore and a legal bank that could be surveyed and mapped by a surveyor under provisions of the Surveys Act. ${ }^{145}$ A body of water differs from the broad term "water body" because all bodies of water have beds, shores, and legal banks that can be established through survey, whereas not all water bodies have these features. For example, many water bodies, such as fens, bogs, peatlands, and temporary or seasonal wetlands, do not have discernible beds, shores, and legal banks that can be determined by survey, and the beds and shores are not claimable as public lands under the PLA. ${ }^{146}$ Therefore the land locations where these water bodies exist are not regulated and controlled as "public lands" if located in private property.

The MMGA definition of a body of water is problematic because it appears to remove municipal jurisdiction to prohibit or regulate and control land use on land consisting of, or adjacent to, certain water bodies, such as temporary and seasonal wetlands, bogs, and fens, because they do not have legal banks determinable through survey, or they are not permanent bodies of water. As a matter of administrative policy under the PLA, a seasonal body of water has water present for five to 17 weeks of the year, and a temporary body of water has water present for less than five weeks of the year. ${ }^{147}$

Given other amendments in the MMGA addressing environmental reserves and conservation reserves discussed later in this article, the requirement for permanency with respect to municipal jurisdiction over water bodies is illogical. The only connection between the MMGA and the permanency criterion is section 3 of the PLA, whereby the beds and shores of permanent and naturally occurring bodies of water are claimed by the province as public lands. ${ }^{148}$ If the beds and shores are public lands by operation of law, how might a municipality ever require a private landowner to dedicate the title to these lands as environmental reserves? A private landowner never owned these lands and cannot transfer title of public lands to a municipality during subdivision processes.

Further, it is posited that it is inadvisable for municipalities to concern themselves with only bodies of water as defined in the MMGA. As the GOA already owns the water in that

$142 \quad P L A$, ibid, s 3(1):

Subject to subsection (2) but notwithstanding any other law, the title to the beds and shores of (a) all permanent and naturally occurring bodies of water, and (b) all naturally occurring rivers, streams, watercourses and lakes, is vested in the Crown in right of Alberta and a grant or certificate of title made or issued before, on or after May 31, 1984 does not convey title to those beds or shores.

143 Water Act, supra note 7, s 1(ggg).

144 Government of Alberta, Guide for Assessing Permanence of Wetland Basins (Edmonton: Alberta Environment and Parks, 2016) at 5, online: <aep.alberta.ca/forms-maps-services/directives/documents/ AssessingPermanenceWetlandBasins-Feb2016A.pdf $>$ [Guidance Document].

145 RSA 2000 , c S-26.

146 Guidance Document, supra note 144 at 4-5.

$147 \quad$ Ibid at 6

148 PLA, supra note $75, \mathrm{~s} 3$. 
subset of water bodies, and may claim the beds and shores of those water bodies, it is precisely the water bodies that are not included in the defined subset that require direction, control, and management by local municipalities. Otherwise there is no level of government to prohibit, regulate, and control private land use on lands consisting of temporary or seasonal wetlands, bogs and fens, or on private riparian lands adjacent to these water bodies. A regulatory gap emerges.

The MMGA definition of a body of water ignores the valuable water storage and release function of temporary and seasonal wetlands, and their importance to local, intermunicipal, and regional scale watershed resilience, and therefore may undermine the municipal purpose of fostering the well-being of the environment. The locations on the landscape where water returns every year in spring snowmelt and during precipitation events are permanent locations where water levels fluctuate over the year. Temporary and seasonal wetlands exist in nature to store and release water at different times of the year. The requirement of permanency (for a water body to have the presence of water for more than seven weeks of the year) is an artificial human construct that does nothing to ensure that municipalities regulate and control the use of lands around these features for watershed resiliency, or for the protection of the aquatic environment, or for preservation of the quality of life of citizens. The end result of the new definition will likely be the continuing, rapid loss of these environmentally significant features and surface water resources that are necessary to mitigate floods and droughts, and to sustain watershed resiliency.

While other provisions in the MMGA support the proposition that municipalities have been granted authority to manage surface water resources at the local and regional scales, this new definition limits the type or subset of water bodies that a municipality has jurisdiction to manage through Part 17 or section 60.

\section{Environmental Reserve Provisions}

The environmental reserve (ER) provisions have been amended dramatically through section 115 of the MMGA, which will undoubtedly lead to increased litigation by developers over property rights until the courts interpret the new legislation. However, the MMGA amendments do support the proposition that municipalities are to consider the environment in a multitude of operational and growth decisions, especially during subdivision approval processes.

In order to fully appreciate the MMGA amendments to the ER provisions, section 664 of the $M G A$ as it currently reads is provided below:

Subject to section 663 and subsection (2), a subdivision authority may require the owner of a parcel of land that is the subject of a proposed subdivision to provide part of that parcel of land as environmental reserve if it consists of

(a) a swamp, gully, ravine, coulee or natural drainage course,

(b) land that is subject to flooding or is, in the opinion of the subdivision authority, unstable, or

(c) a strip of land, not less than 6 metres in width, abutting the bed and shore of any body of water. ${ }^{149}$ 
Since enactment in 1994, the above ER provision has been the subject matter of many municipal subdivision and development appeal board, Municipal Government Board, and court decisions because the municipality is not required to compensate the landowner for ER dedications. As well, over time, with more sophisticated scientific tools at their disposal, municipalities have required much wider strips of land (greater than 6 metres) to be dedicated in riparian lands abutting water bodies in accordance with section 664(1)(c), in order to mitigate against pollution and to provide public access.

Through MMGA amendments, section 664(1) of the MGA is now subject to section 663 of the MGA and section 664(2), regarding ER easements for the protection and enhancement of the environment. In the MGA, ER easements are institutional arrangements whereby the landowner and the municipality agree, prior to an application to subdivide a parcel of land, that the lands that would otherwise be required to be dedicated to the municipality as environmental reserves will carry a municipal easement whereby the lands will remain in their natural state. The title to the lands covered by the easement remains with the landowner, and runs with any disposition of the land. The ER easement constitutes an interest in the land that may be enforced by the municipality. ${ }^{150}$ Following subdivision, the landowner continues to control public access to the lands covered by the easement.

Under the MGA, before the MMGA amendment, municipalities tended to require the dedication of ERs without considering ER easements as a first option. ER parcels were often used for other municipal purposes, such as public parks and recreational facilities, as well as for pathways, and water and wastewater treatment and distribution systems, even though the ER parcels were originally considered undevelopable lands. By giving the municipality discretion to require dedication of lands as ER during subdivision processes subject to agreements for ER easements, the GOA has directed municipalities to retain these lands in their natural state for the protection and enhancement of the environment in the public interest. Arguably, the GOA intended that private landowners continue to control access to these landscapes.

The new definition of body of water complicates the interpretation of the changes to the ER provisions, especially section 664(1)(c). First, through MMGA amendments, section 664(1)(c) of the MGA is repealed and replaced by: "(c) a strip of land, not less than 6 metres in width, abutting the bed and shore of any body of water." 151 By way of comparison, previously, section 664(1)(c) did not require that a body of water be permanent or naturally occurring as a condition of requiring the dedication of the minimum 6 metre strip of land from its bed and shore. As well, the two purposes for requiring the dedication of ER strips abutting water bodies were repealed and replaced with a list of four purposes that apply to all subsections of section 664(1), not just 664(1)(c) as before. Section 664(1.1) is a substantive amendment to the ER provisions, as follows:

A subdivision authority may require land to be provided as environmental reserve only for one or more of the following purposes:

$150 \quad$ Ibid, ss 664(2)-(3).

151 Ibid, s 664(1)(c). See also ibid, s 640(4)(1)(ii), where the new definition limits the broad application of the section as it was previously enacted. 
(a) to preserve the natural features of land referred to in subsection (1)(a), (b) or (c) where, in the opinion of the subdivision authority, those features should be preserved;

(b) to prevent pollution of the land or of the bed and shore of an adjacent body of water;

(c) to ensure public access to and beside the bed and shore of a body of water lying on or adjacent to the land;

(d) to prevent development of the land where, in the opinion of the subdivision authority, the natural features of the land would present a significant risk of personal injury or property damage occurring during development or use of the land. ${ }^{152}$

In addition, interpretation of what the GOA means by "bed and shore" is added in a new provision, section 664(1.2), as follows: "[f]or the purposes of subsection (1.1)(b) and (c), 'bed and shore' means the natural bed and shore as determined under the Surveys Act." "153

The bed and shore will necessarily need to be determined by a surveyor in order to establish an appropriate reserve setback to achieve one or more of the purposes of an ER listed in section 664(1.1), above.

By adding the four new purposes to the requirement for dedication in section 664(1.1), more lands will likely be required to be dedicated that did not meet the previous limiting purpose criteria. For example, in the past, to require the dedication of a minimum 6 metre strip of land abutting water bodies as they were previously listed in section 664(1)(c) preamendment, a municipal development authority had to be able to demonstrate that the requirement was for providing public access or preventing pollution. Under the MMGA amendments, 6 metre (or much wider) strips may now be required to be dedicated for two additional purposes, including the broadly stated purpose "to preserve the natural features of land referred to in subsection (1)(a), (b) or (c) where, in the opinion of the subdivision authority, those features should be preserved." 154 The four new purposes will enable the requirement for an ER dedication of more environmentally significant areas, and will, arguably, render the conservation reserve provisions redundant (this is discussed further below). Further, if more lands are required to be dedicated as environmental reserve "in the opinion of the subdivision authority," there will be less land left in the parcel from which to calculate the 10 percent requirement of developable lands for much-needed municipal and school reserves. ${ }^{155}$ Land population density requirements in many communities may no longer be achievable.

Additionally, given the above discussion about the MMGA definition of body of water, how will municipalities know if they have jurisdiction to require the dedication of lands as ER under section 664 that consist of, or are riparian lands that abut bogs, fens, peatlands, and ephemeral wetlands? Arguably, the provisions in sections 664(1)(a) and (b) already address these features and provide that they may be required to be dedicated as ER. For example, the term "swamp" in section 664(1)(a) reflects terminology that was imported into Canadian law from the British legal system. Swamps traditionally had no discernible beds and shores or legal banks, so, arguably, section 664(1)(a) provided enabling legislation to municipalities so that they could require dedication of lands as ER that contained bogs, fens, peatlands, and 
ephemeral wetlands that were not bodies of water with a discernible bed and shore or legal bank. However, these lands were not suitable for residential or commercial development because of inherent risks of flooding and subsidence.

In section 664(1)(b), the phrase "land that is subject to flooding" includes flood risk areas (both the floodway and the flood fringe as defined in Alberta's Flood Hazard Identification Program), ${ }^{156}$ and ephemeral wetlands that only flood during spring snowmelt and high precipitation events. These lands are highly productive riparian landscapes (surface water resources) that store and release water during drought and flood conditions. Section $664(1)(b)$ does not refer to beds and shores of bodies of water, but allows a municipality to require the dedication of ephemeral wetlands and lands in the flood fringe of water bodies as ER. These substantive changes to the ER provisions illustrate provincial direction to municipalities to conserve and manage bodies of water as defined, and other surface water resources and environmentally significant areas at the local scale, especially during subdivision approval processes.

\section{E. NEW "CONSERVATION RESERVES"}

"Conservation reserves" are new institutional arrangements created through section 114 of the MMGA. Unlike ER dedications, a conservation reserve required to be transferred to a municipality during the subdivision process is considered a taking for which the municipality must pay full market value. ${ }^{157}$ Conservation reserves will, therefore, be recognized as valuable, environmentally significant features as part of MDP and Area Structure Plan development processes.

Municipalities will need to expend general revenues to identify and map these environmentally significant features during statutory planning processes well in advance of a landowner or developer's application for subdivision and development of the parcel. This is because a land developer who purchases lands expecting to be able to use the land for development purposes should not be surprised by a requirement to sell these lands to the municipality as conservation reserves after buying the land to develop. The new section, 664.2, is provided below in its entirety as follows:

(1) A subdivision authority may require the owner of a parcel of land that is the subject of a proposed subdivision to provide part of that parcel of land to the municipality as conservation reserve if

(a) in the opinion of the subdivision authority, the land has environmentally significant features,

(b) the land is not land that could be required to be provided as environmental reserve,

(c) the purpose of taking the conservation reserve is to enable the municipality to protect and conserve the land, and

(d) the taking of the land as conservation reserve is consistent with the municipality's municipal development plan and area structure plan.

156 See Government of Alberta, "Flood Hazard Identification Program,” online: Alberta Environment and Parks < aep.alberta.ca/water/programs-and-services/flood-hazard-identification-program/default.aspx > . See MGA, supra note 1, s 661.1, which introduces conservation reserves: "[ $\mathrm{t}$ ] land that is the subject of a proposed subdivision must provide to a municipality land for conservation reserve as required by the subdivision authority pursuant to this Division." 
(2) Within 30 days after the Registrar issues a new certificate of title under section 665(2) for a conservation reserve, the municipality must pay compensation to the landowner in an amount equal to the market value of the land at the time the application for subdivision approval was received by the subdivision authority.

(3) If the municipality and the landowner disagree on the market value of the land, the matter must be determined by the Land Compensation Board. ${ }^{158}$

Conservation reserves reflect the GOA's intent that municipal governments are to protect and conserve environmentally significant features within their boundaries that are not otherwise dedicated as ER pursuant to section 664. While this new provision clarifies that a municipality must compensate the landowner for lands required to be dedicated as conservation reserve, it does not describe what lands could possibly fit under this description when section 664 adequately allows for the dedication of most environmentally significant features as ER. In all probability, litigation will arise over conservation reserves because municipalities will likely use the expanded purposes in section 664(1.1) to avoid ever having to purchase conservation reserves. As lands owned by the municipality after subdivision, they will attract public access and intensive recreational use by citizens. In order to protect and conserve these lands, municipalities will need to manage human uses and activities, and therefore manage the lands.

Conservation easements under ALSA seem to be better tools to achieve conservation of environmentally significant features because, as voluntary arrangements between a landowner and a municipality as the easement holder, the lands will be stewarded to a higher standard by the landowner who can restrict public access. Municipalities have not always been the best stewards of environmentally significant features. For example, municipalities do not adequately control human access, do not manage invasive species, and often use these landscapes for dog parks, and other inappropriate human uses. Across the province, ER parcels (which represent some of the most environmentally significant features in Alberta) are regularly used for roads, pathways, dog parks, water and wastewater treatment facilities, recreational facilities, recreational vehicle campgrounds, and so on.

However, as part of a modernized legislative scheme for municipal government, conservation reserve legislation signals the GOA's intent that municipalities have responsibility to manage environmentally significant features in the overall greater public interest. This intention is reflected throughout the MMGA amendments enabling and regulating IDPs, ICFs, GMBs, and city charters. It should be noted that "environmentally significant features" have not been defined in the amending legislation and the term may not have the same meaning as "environmentally significant areas" that have been identified in different parts of the province.

\section{CONCLuSion}

In Dunsmuir v. New Brunswick, Justices Bastarache and LeBel, speaking for the majority of the Supreme Court of Canada, stated "[b]y virtue of the rule of law principle, all exercises of public authority must find their source in law. All decision-making powers have legal limits, derived from the enabling statute itself, the common or civil law or the 
Constitution." ${ }^{\prime 159}$ As creatures of the GOA, municipalities may only manage surface water resources and air quality within their boundaries in accordance with the municipal purposes, powers, and limitations provided in the MGA and the common law.

Amendments to the MGA since 2015 are part of a larger legislative scheme to modernize municipal government in Alberta. The amendments examined in this article support that municipalities are authorized to manage surface water resources and air quality, and to engage in environment management activities at a range of scales, including local, city, intermunicipal, growth region, and regional. The clear limitations on municipal powers to enact bylaws, pass resolutions, and engage in environmental management activities continue to be that all municipal environmental management bylaws, decision-making processes, and activities must be undertaken to achieve one or more municipal purposes, according to the powers granted to municipalities by the GOA, and they must be consistent with enactments and regional plans, except, perhaps, the city charter provisions.

Although municipalities throughout Alberta had engaged locally and collectively in the management of local surface water resources, and to some extent air quality management well before the MMGA was enacted, the MGA's preamble, new purpose statement, and institutional arrangements for GMBs, ICFs, and, notably, IDPs that require municipalities to address intermunicipal environmental matters will expand municipal authority to engage in environmental management programs and projects at other scales, such as cities through city charters, intermunicipal planning areas, growth regions, and watershed-scale regional plan areas.

In conclusion, fact patterns, the wording and interpretation of statutory provisions, and legal precedents arising from Canadian court decisions about municipal jurisdiction will continue to affect legal opinions on the question of whether municipalities have authority to manage surface water resources and air quality at any scale. However, since the enactment of the MMGA and An Act to Strengthen, Alberta courts will have more to work with when required to determine whether municipalities have exceeded their jurisdiction in enacting environmental management bylaws to foster the well-being of the environment. 